\title{
Riparian and valley-margin hardwood species of pre-colonial Piedmont forests: \\ A preliminary study of subfossil leaves from White Clay Creek, southeastern Pennsylvania, USA
}

\author{
Sara J. Elliott, Christen L. Grettenberger, Michael P. Donovan, \\ Peter Wilf, Robert C. Walter, and Dorothy J. Merritts
}

\begin{abstract}
Beginning in the seventeenth century, colonial activities such as land clearing, agriculture, and milldam construction significantly altered the landscapes, vegetation, and hydrogeomorphology of the northeastern Piedmont region, modern-day USA. Presently, weedy and non-native vegetation dominate the altered riparian zones and hill slopes where old-growth, hardwood forests once prevailed. Various studies have identified pre-settlement herbaceous wetland floras based on fruits and seeds. However, only one report provided evidence of the dominant pre-settlement woody species by using the localized signal available from subfossil leaves; that work reconstructed Maple-Ash floodplain swamp forests along valley-margins and Oak-Beech mixed forests on upper-slopes at a site in Lancaster County, southeastern Pennsylvania. Here, we investigate subfossil leaves recovered from the buried wetland soils of White Clay Creek in neighboring Chester County, Pennsylvania, providing significant new spatial data to our understanding of regional old-growth forests. The leaf assemblage, radiocarbon dated to ca. 1650, is composed of woody species with a diverse range of wetland affinities, indicating sources in both the riparian zone and surrounding lower hill slopes. Obligate and facultative-wetland species include willow (Salix spp.) and Hazel Alder (Alnus serrulata). Box Elder (Acer negundo) is the only facultative species present, while American Beech (Fagus grandifolia), the white and red oak groups (Quercus Section Quercus and Q. Section Lobatae, respectively), and Tulip Tree (Liriodendron tulipifera) comprise the identified facultative-upland taxa. These results complement and corroborate previous work and allow for greater confidence in understanding the pre-European landscape, potentially increasing the effectiveness of regional environmental restoration projects.
\end{abstract}

Sara J. Elliott. Department of Geosciences, Pennsylvania State University, University Park, PA 16802, USA; Bureau of Economic Geology, University of Texas, Austin, TX 78758, USA.

sara.elliott@beg.utexas.edu (corresponding author)

Christen L. Grettenberger. Department of Geosciences, Pennsylvania State University, University Park, PA 16802, USA.

Elliott, Sara J., Grettenberger, Christen L., Donovan, Michael P., Wilf, Peter, Walter, Robert C., and Merritts, Dorothy J. 2016. Riparian and valley-margin hardwood species of pre-colonial Piedmont forests: A preliminary study of subfossil leaves from White Clay Creek, southeastern Pennsylvania, USA. Palaeontologia Electronica 19.1.2A: 1-26

palaeo-electronica.org/content/2016/1379-pre-colonial-piedmont-forests 
Michael P. Donovan. Department of Geosciences, Pennsylvania State University, University Park, PA 16802, USA.

Peter Wilf. Department of Geosciences, Pennsylvania State University, University Park, PA 16802, USA. Robert C. Walter. Department of Earth and Environment, Franklin and Marshall College, Lancaster, PA 17604, USA.

Dorothy J. Merritts. Department of Earth and Environment, Franklin and Marshall College, Lancaster, PA 17604, USA.

Keywords: paleobotany; Holocene; leaves; paleoecology; restoration; milldams

Submission: 27 July 2015 Acceptance: 30 November 2015

\section{INTRODUCTION}

European settlement in eastern North America was characterized by severe and rapid anthropogenic landscape modifications, including changes in stream hydrology and riparian forest ecology (Foster et al., 1998; Cogbill, 2000; Walter and Merritts, 2008; Thompson et al., 2013). Deforestation, agriculture, and milldam construction during the seventeenth through nineteenth centuries in the Piedmont region profoundly altered fluvial geomorphology, resulting in the deposition of up to several meters of fine-grained "legacy" sediments above pre-existing wetland soils along many Piedmont valley-bottoms. Through subsequent dam breaching, the once-broad wetlands were converted into incised streams with unstable banks, primarily supporting weedy and non-native vegetation (Walter and Merritts, 2008; Hartranft et al., 2011; see Appendix 1 and Elliott et al., 2013 for additional information regarding historical background). To this day, Piedmont streams carry anomalously high concentrations of suspended sediments (Walter et al., 2007; Gellis et al., 2009; Pizzuto and O'Neal, 2009; Merritts et al., 2013; Voli et al., 2013), which contribute significantly to contemporary nutrient loading in downstream watersheds such as the Chesapeake Bay. The resulting algal blooms and eutrophication are detrimental to wildlife such as marine plants, algae, and benthic organisms (Orth and Moore, 1983; Pennock et al., 1994; Boesch et al., 2001; Stanley and Doyle, 2002; Kemp et al., 2005; Kennen et al., 2010; Merritts et al., 2010a; Niemitz et al., 2013; James, 2013; Sharpley et al., 2013; Hupp et al., 2015).

Damming, sediment accumulation, and later stream incision also significantly affected the floral assemblages in the riparian zone (Voli et al., 2009; Merritts et al., 2013; Appendix 1) and the valleymargin and upslope hardwood communities (Elliott et al., 2013), producing a landscape that contrasts starkly with the sluggish, low-gradient, pre-colonial wetlands (Hilgartner and Brush, 2006; Walter and
Merritts, 2008). Ultimately, the increased distance to the water table, paired with the well-drained legacy sediments, excluded native wetland species whose roots could no longer reach the water table or extract moisture from the silty soils (Shafroth et al., 2002; Stanley and Doyle, 2003). Over time, plants better adapted to dry conditions, frequently exotic species, replaced the native wetland flora (Walter et al., 2007; Walter and Merritts, 2008, figure 3c; Voli et al., 2009; Gutshall and Oberholtzer, 2011; Kim et al., 2015). Loss of the native flora and subsequent invasion of weedy species continue to have substantial impacts on ecosystem function because riparian zones, especially those rich in hardwood trees, increase bank stability, serve as important sinks for sediments and nutrients, filter pollutants, and provide habitat for native fauna (Correll et al., 1992; FISRWG, 2008; Hartranft et al., 2011; Gutshall and Oberholtzer, 2011; Macfall et al., 2014).

Potential environmental remediation of the heavily settled Piedmont, as well as historical understanding of the riparian forests that once supported native and settler populations, ultimately depend on accurate botanical knowledge of the pre-colonial landscape. Unfortunately, virtually no historical accounts provide detailed records of the lost vegetation, which is now being reconstructed using paleobotanical data from buried, prehistoric wetland (hydric) soils preserved at a handful of sites (for additional information regarding the potential benefits of paleobotanical data for environmental remediation, see Elliott et al., 2013, and Appendix 2).

Previously published fruit and seed data from the hydric soil layer at Big Spring Run in Lancaster County, Pennsylvania (Chesapeake Watershed) indicate that the pre-settlement flora was rich in herbaceous wetland species, such as Carex (sedges), Polygonum (Knotweed), and Eleocharis (spikerushes), as well as occasional woody, nonwetland taxa interpreted to be from valley-margins, 
including Liriodendron tulipifera (Tulip Tree) and Juglans cinerea (Butternut; Voli et al., 2009; Hartranft et al., 2011). Radiocarbon dating of the recovered fossil seeds indicated that a patchwork of wetland environments containing the aforementioned species may have been widespread from at least $3200 \mathrm{ybp}$ (years before present) until the arrival of European settlers approximately 300 years ago (Voli et al., 2009). However, presumably due to biases in fruit and seed preservation (e.g., Behrensmeyer et al., 2000), the Big Spring Run data provide a very limited view of woody riparian and upslope species.

In contrast, another recent study from Denlingers Mill, also in Lancaster County and the Chesapeake Watershed, detailed valley-margin and upslope hardwood communities based on 11 recovered species of pre-settlement subfossil leaves and some fruits, dating to the early 1700 s (Elliott et al., 2013). Subfossil leaves are rarely used by paleontologists because of their extreme fragility, but because they are minimally transported and temporally mixed compared to more commonly studied seeds and pollen, they can provide detailed, localized views of past landscapes that are not usually available otherwise (see Appendix 3 for additional information regarding the use of leaves versus fruits, seeds, and pollen in this research). Elliott et al. (2013) was the first study that used subfossil leaves in this region. That work concluded that Red Maple-Black Ash Swamp forests and Oak-Beech mixed hardwood forests dominated the pre-settlement valley-margin and upslope hardwood communities, respectively. Elliott et al. (2013, figure 17) also provided a detailed artist's reconstruction of the riparian, valley-margin, and upslope pre-settlement landscape reconstructed from paleobotanical data. The results from Elliott et al. (2013) demonstrated the significance of delicate, negligibly transported subfossil leaves for localized reconstructions of presettlement landscapes and the need for new subfossil leaf sites, such as White Clay Creek, to improve spatial understanding.

Here, we investigate a preliminary collection of leaf subfossils from buried wetland soils located directly beneath accumulated legacy sediments on White Clay Creek, Chester County, Pennsylvania, part of the Delaware Watershed (Figure 1; Miller, 2011). We consider our findings "preliminary" because of the relatively small sample size and fragmentary nature of the material so far collected from the field site ( 26 of 62 specimens were identifiable; Appendix 4). Our goals are to contribute crit-

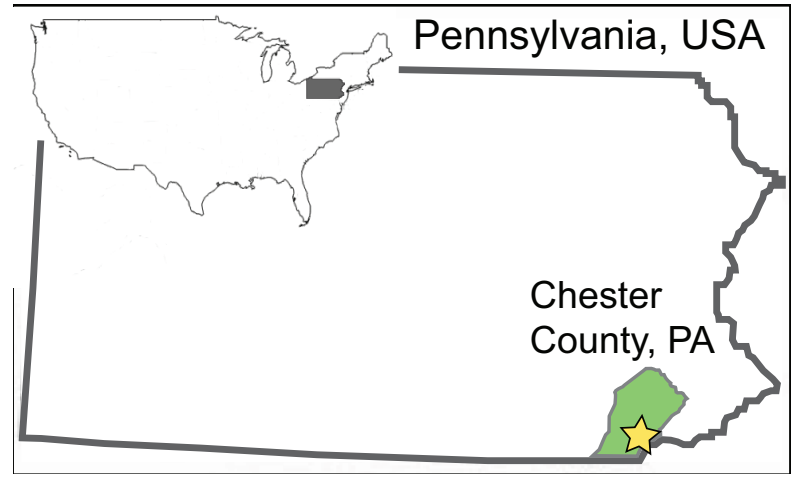

FIGURE 1. Location of the White Clay Creek leaf mat site, Chester County, Pennsylvania.

ical spatial knowledge to our overall understanding of the pre-settlement, valley-bottom Piedmont landscape, and to test the emerging consensus that the pre-colonial riparian flora was much richer in wetland-affiliated hardwood species than today. Furthermore, knowledge of the pre-settlement flora can improve the success of stream, wetland, and floodplain restoration because plant assemblages directly impact wetland and fluvial geomorphology and hydrology (Richardson et al., 2007; Macfall et al., 2014; Appendix 2).

\section{METHODS}

The study site is located in southeastern Pennsylvania on the eastern branch of White Clay Creek in Chester County, approximately $65 \mathrm{~km} \mathrm{W-}$ SW of Philadelphia ( $39^{\circ} 51.7^{\prime} \mathrm{N}, 75^{\circ} 47.0^{\prime} \mathrm{W}$; Figures 1,2 ) in the Piedmont physiographic province of the Appalachian Highlands. This region is composed of broad rolling hills and valleys underlain by both carbonate and schistose basement rock (Fenneman, 1938). The eastern branch of White Clay Creek drains through the Precambrian Cockeysville Marble, the Lower Paleozoic Wissahickon Schist, and various Lower Paleozoic gneisses (Blackmer, 2004). White Clay Creek is a 3rd order stream within the Christina River drainage system, which eventually feeds into the Delaware Bay. Land adjacent to the creek is approximately $52 \%$ open pasture, $22 \%$ agriculture, $3 \%$ residential, and $23 \%$ forested, the latter mostly in some stage of regrowth following restoration (Newbold et al., 1997).

A stratigraphic section at the study site was measured and described at the centimeter scale (Table 1) and was found to fit the composite profile of modified Piedmont streams (Walter and Merritts, 2008). Prior to examination, the stream bank was cleared, and a fresh vertical surface was exposed 


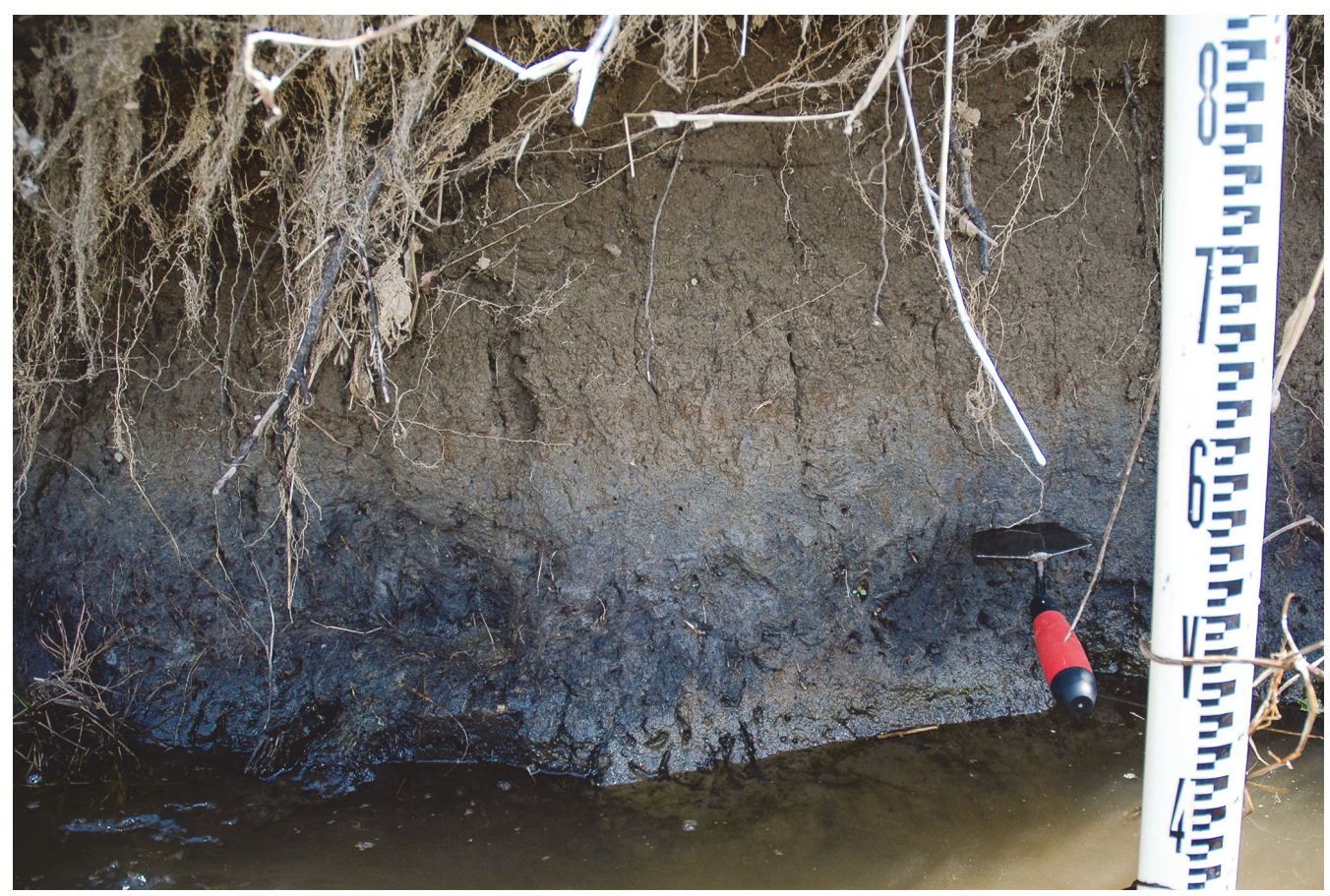

FIGURE 2. White Clay Creek leaf mat site, illustrating the contact (at trowel) between the darker hydric soil layer containing subfossil leaves and the overlying, lighter-colored legacy sediments. Stadia rod for scale.

TABLE 1. Stratigraphy of the White Clay Creek site.

\begin{tabular}{|c|c|c|c|c|c|}
\hline $\begin{array}{l}\text { Layer } \\
\text { Number }\end{array}$ & $\begin{array}{l}\text { Height } \\
(\mathrm{cm})\end{array}$ & $\begin{array}{l}\text { Thickness } \\
\text { (cm) }\end{array}$ & $\begin{array}{c}\text { Plant } \\
\text { Subfossils }\end{array}$ & $\begin{array}{c}\text { Radiocarbon } \\
\text { Dating Samples }\end{array}$ & Description \\
\hline 9 & $110-117$ & 7 & No & No & Modern soil and roots. No cross strata. \\
\hline 8 & $103-110$ & 7 & No & No & $\begin{array}{l}\text { Fine to very fine sand layer directly below modern } \\
\text { soil and roots. Overhangs stream bank. }\end{array}$ \\
\hline 7 & $40-103$ & 63 & No & No & $\begin{array}{l}\text { Silt, light brown, finely laminated legacy sediment. } \\
\text { No cross strata. }\end{array}$ \\
\hline 6 & $37-40$ & 3 & No & No & $\begin{array}{l}\text { Silt and clay with occasional fine sand grains. } \\
\text { Moderate brown when wet. No cross-strata. }\end{array}$ \\
\hline 5 & $33-37$ & 4 & No & No & $\begin{array}{l}\text { Silt, dark yellow-brown when wet, dusky yellow } \\
\text { when dry. No cross-strata. }\end{array}$ \\
\hline 4 & $26-33$ & 7 & No & No & $\begin{array}{l}\text { Silt at base, coarsening upwards to fine sands at } \\
\text { top. Dark yellow-brown when wet, dusky yellow } \\
\text { when dry. Lightens in color upwards. Fine roots and } \\
\text { occasional small stick fragments. No cross-strata. }\end{array}$ \\
\hline 3 & $19-26$ & 7 & Top of layer & UGAMS 07518 & $\begin{array}{l}\text { Clay matrix with mica flecks, dusky brown when } \\
\text { wet. Little to no plant debris, mainly fine roots with } \\
\text { occasional leaf fragments and embedded sticks. No } \\
\text { cross-strata. }\end{array}$ \\
\hline 2 & $7-19$ & 12 & Middle of layer & UGAMS 07517 & $\begin{array}{l}\text { Clay matrix with mica flecks, dusky brown when } \\
\text { wet. Less plant debris than layer below, and more } \\
\text { fragmented when present. No cross-strata. }\end{array}$ \\
\hline 1 & $0-7$ & 7 & Bottom of layer & UGAMS 07516 & $\begin{array}{l}\text { Pebbles and plant debris embedded in clay matrix, } \\
\text { dusky brown when wet with mica flecks. Contains } \\
\text { the majority of leaf subfossils. No cross-strata. }\end{array}$ \\
\hline
\end{tabular}


to ensure accurate descriptions of grain size, Munsell color, and presence or absence of cross strata and subfossils. The hydric soil layer (buried wetland), the source of all subfossils used in this study, is approximately $25 \mathrm{~cm}$ thick and overlies basal cobbles and schistose basement rock; it contains plant subfossils, including seeds, leaves, and twigs, especially within the lowest $7 \mathrm{~cm}$. Above the hydric soil layer sit approximately $10 \mathrm{~cm}$ of rust-colored sandy clay, and above that lie approximately $60 \mathrm{~cm}$ of finely laminated, light-brown silt, in turn overlain by modern soil and vegetation.

Subfossil plant material was collected three times from October 2009 to October 2010. Blocks of the hydric soil layer that were especially fossiliferous were transported in stream water to the Sedimentology and Paleobotany laboratories at Penn State University, where they were stored in 50-50 ethanol and stream water.

Three leaf fragments, taken directly from the lower, middle, and top of the hydric soil layer, respectively (Table 1 ), were sent to the Center for Applied Isotope Studies at the University of Georgia for accelerator mass spectrometry (AMS, sample acronym UGAMS) radiocarbon dating (Table 2). Radiocarbon (carbon-14), with a half-life of 5,730 years, is produced in the atmosphere from the interaction of secondary cosmic ray neutrons with nitrogen-14. Radiocarbon mixes with nonradiogenic carbon, which together are assimilated by carbon molecules in living organisms. At death, carbon-14 disintegration is uncompensated, and the decay clock begins. As a general rule, the maximum duration since death can be determined to about five half-lives (ca. 30,000 years). Radiocarbon ages are reported in yr BP, which, unlike ybp, refers to the year $1950 \mathrm{CE}$ as the reference date. Based on radiocarbon dating of fossil seeds and fruits, similar hydric soil layers in the Piedmont region have been dated to between 300 and 11,500 ybp (Walter and Merritts, 2008).
Leaves (and a few fruits) were cleaned of debris via alternating washes of $40 \% \mathrm{HCl}(\mathrm{pH}$ of $\sim 1$ ), to remove silicates, and Calgon liquid water softener (Reckitt Benckiser, Slough, Berkshire, England; $\mathrm{pH}$ of $\sim 9$ ) to remove organics. Acid washes were done over five to ten days. The Calgon washes involved soaking leaves and leaf fragments in a $30-50 \%$ solution for three to seven days; this product contains a polycarboxylate that prevents re-deposition of organics by interfering with the electrostatic interactions between clay particles and the leaf surface, while not destroying leaf tissue (Blockhaus et al., 1996; Traverse, 2008). The washes were repeated as necessary, up to three repetitions per sample, until the leaf surface was greater than $90 \%$ clear. We tried sonication as an alternate, rapid method for debris removal, but this unacceptably damaged the leaves.

Immediately prior to mounting, leaf fragments were dehydrated in a graded series of baths, increasing from $50 \%$ to $100 \%$ ethanol. As a final dehydration step, leaf fragments were placed in two xylene baths for five minutes each. Leaves were then mounted on glass slides using Cytoseal 280 High Viscosity Mounting Medium (Richard Allen Scientific Inc., Kalamazoo, Michigan, USA), when possible with the abaxial surface facing upwards to highlight venation. The total sample of mounted subfossil specimens was 60 leaves and two fruits. All specimens are deposited in the Earth and Mineral Sciences Museum of Pennsylvania State University (EMS; Appendix 4).

Once mounted, each sample was viewed using transmitted and epifluorescent light with both a Nikon SMZ-1500 stereomicroscope and a Nikon LV100 compound microscope (Nikon, Melville, New York, USA), an X-Cite 120 Epifluorescence Illumination Unit (EXFO Electro-Optical Engineering, Quebec City, Quebec, Canada), and an Endow GFP Longpass Emission Green Filter (Chroma Technology Number 41018, exciter

TABLE 2. Radiocarbon results for leaf subfossils from White Clay Creek (Table 1). * Best-fit intercept age calibrated using CALIB REV7.1.0 Radiocarbon Calibration Program (Reimer et al., 2013). The "mean probability" ages for these units are 1774, 1562, and $1778 \mathrm{CE}$, for Base, Middle and Top samples, respectively. The selected calibrated $2 \sigma$ intercepts of 282, 311, and $282 \mathrm{yr}$ BP (before 1950) shown above, and chosen among several possible intercept ages, represent the dates that best fit the measured ${ }^{14} \mathrm{C}$ ages in combination with the stratigraphic order of the samples.

\begin{tabular}{cccc}
\hline Sample \# & Name & $\begin{array}{c}\text { 14C Age, Years BP, } \\
\text { Uncalibrated } \\
\text { Radiocarbon Age }\end{array}$ & $\begin{array}{c}\text { 14C Age, Years BP, Calibrated 2 } \sigma^{*} \\
\text { (Range = CE) }\end{array}$ \\
\hline UGAMS 07518 & LMS Top & $200 \pm 20$ & $282+/-14(1654-1682)$ \\
UGAMS 07517 & LMS Middle & $290 \pm 25$ & $311+/-22(1617-1660)$ \\
UGAMS 07516 & LMS Base & $200 \pm 25$ & $282+/-16(1652-1683)$ \\
\hline
\end{tabular}


HQ470/40x, diachronic Q49LP BS, emitter HQ500LP, Chroma Technology, Rockingham, Vermont, USA), then photographed using a Nikon Digital Sight DS-Ri1 camera with Nikon NIS Elements v. 3 Basic Research software. Adobe Photoshop CS5 (Adobe Systems Incorporated, San Jose, California, USA) was used to compose stacked or stitched composite images when necessary.

Leaf specimens were described following Ellis et al. (2009), supplemented with Stearn (2004); because samples were fragmented, not all characters could be described for all specimens. Additionally, foliar trichomes found on abaxial surfaces were used to improve identifications, especially within the family Betulaceae and genera Quercus and Salix, using the Atlas of Foliar Surface Features in Woody Plants I, VIII, and IX (Hardin, 1979; Hardin and Johnson, 1985; Hardin and Bell, 1986). Noting that trichomes are typically lost during fossilization, only the presence, not the absence, of particular trichome types was used to increase taxonomic resolution.

Cleared leaf images from the Jack A. Wolfe USGS National Cleared Leaf Collection, housed at the National Museum of Natural History of the Smithsonian Institution, and from the Daniel Axelrod Cleared Leaf Collection, housed at the University of California Museum of Paleontology, Berkeley, as well as mounted leaves from PW's York County, Pennsylvania collections (Wilf, 1997) were used as references for identification. Because it was unlikely that the pre-settlement flora contained exotic or invasive species, only species native to Pennsylvania and surrounding states were considered in this study. Classifications follow Angiosperm Phylogeny Group III (APG III, 2009).

\section{RESULTS}

\section{Radiocarbon dating}

Calibrated radiocarbon results for three samples collected from the base, middle and top of the fossiliferous layer indicate deposition between 311 \pm 22 and $282 \pm 15$ yr BP (before 1950; i.e., between 1639 and 1668 C.E.; Table 2). The mean probability age for the subfossil dated from the middle portion of the hydric soil layer is temporally displaced compared to the sample from the basal layer (see Table 2 notes), possibly indicating local reworking. However, the base and top subfossils yielded identical measured ${ }^{14} \mathrm{C}$ ages (Table 2 ) and, further, each of the three samples yielded multiple intercepts on the calibrated radiocarbon curve of Reimer et al. (2013). The one intercept in common among these three samples, which agree at the $2 \sigma$ level of confidence, produced tightly constrained calibrated ages shown in Table 2. For this reason, we consider all paleobotanical samples as a single, lumped assemblage. The resulting temporal averaging is minimal because the leaves were likely deposited in a short period of time around $300+/-$ 20 yr BP (i.e., 1650 C.E.). No permanent European settlements existed in Pennsylvania prior to 1638 (Weslager, 1955), and the leaf layer lies immediately underneath colonial-era legacy sediments. The combined evidence indicates that the leaves were deposited immediately prior to, or during the initial stages of, European settlement in the local area. We interpret that this leaf mat horizon was deposited in a shallow pool in or near the valley margin of a widespread pre-settlement wetland.

\section{White Clay Creek subfossil flora}

The preliminary subfossil assemblage described below is composed of seven hardwood taxa with a diverse range of wetland affiliations, indicating that the leaves and occasional fruits originated from both the riparian zone and surrounding lower hill slopes. Alnus serrulata (Hazel Alder) and Salix (willow) have either wetland-obligate or facultative-wetland indicator status, meaning that they occur in wetlands 67 to $99 \%$ of the time. Acer negundo (Box Elder) is the only facultative species, signifying that it is equally likely to represent wetland and upland environments. Four taxa, namely the red and white oaks (Quercus Section Quercus, Q. Section Lobatae), Tulip Tree (Liriodendron tulipifera), and American Beech (Fagus grandifolia) are considered facultative-upland, meaning they occur in uplands $67-99 \%$ of the time and, therefore, have a reduced chance of being part of a wetland or riparian forest assemblage.

Family BETULACEAE Gray, 1821

Genus ALNUS Miller, 1754

Alnus serrulata (Aiton, 1789) Willdenow, 1805

Figure 3

Material. EMS 425002.

Description. Laminar size microphyll, length to width ratio 4:3. Laminar shape unlobed elliptic, with medial symmetry; base not preserved. Primary venation pinnate. Major secondary veins craspedodromous with excurrent attachment to midvein, spacing smoothly decreasing proximally. Intercostal tertiary veins opposite percurrent, convex or sinuous, perpendicular to midvein, angle consistent. Epimedial tertiary veins opposite percurrent, proximal course obtuse to midvein, distal course parallel to intercostal tertiary. Quaternary vein fabric irregu- 

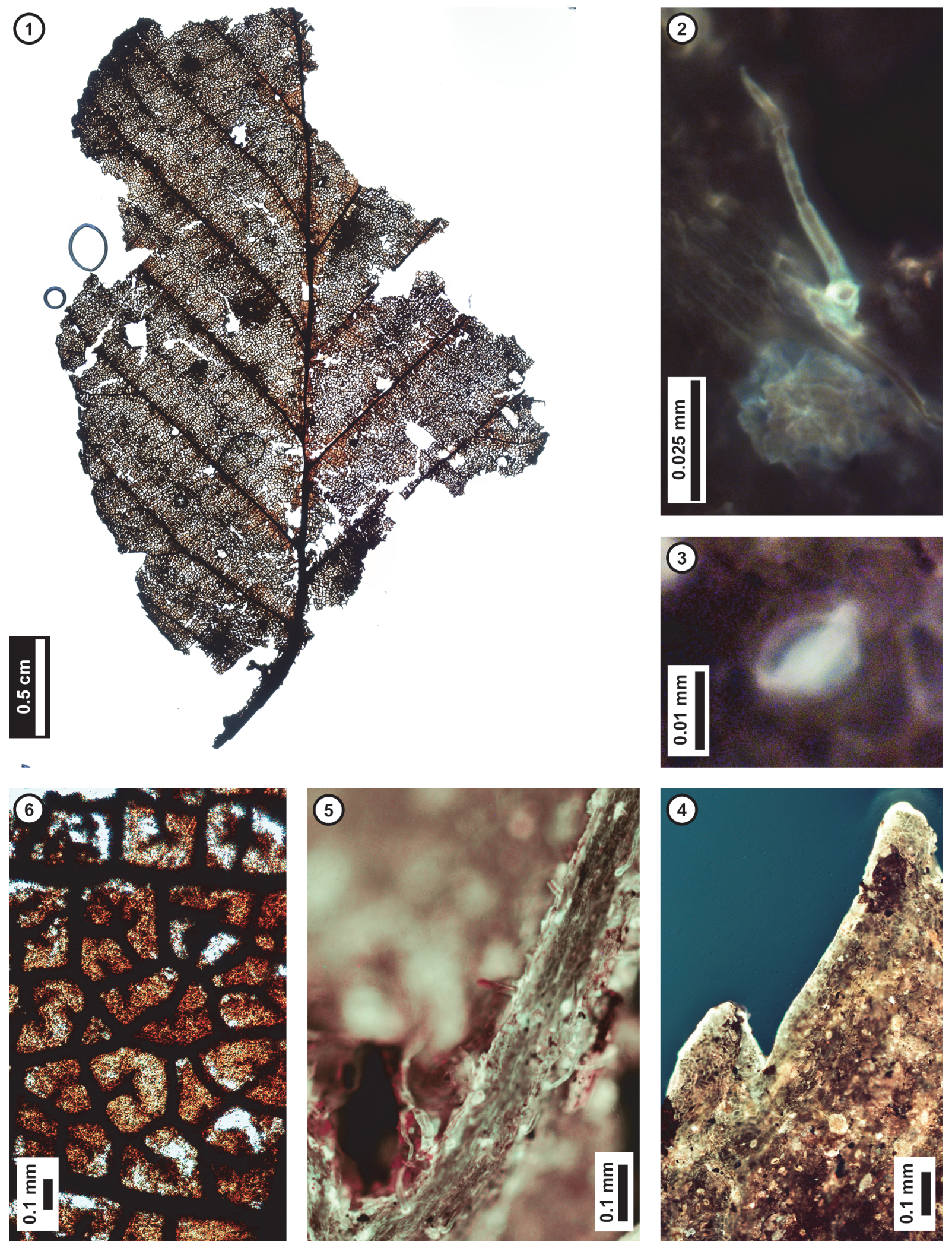

FIGURE 3. Alnus serrulata (Hazel Alder), EMS 425002. 1, Whole specimen; 2, Peltate scale and simple trichomes; $\mathbf{3}$, Stipitate gland trichome; $\mathbf{4}$, Detail of teeth; $\mathbf{5}$, Trichomes at vein junction; $\mathbf{6}$, Areolation with simple and branching freely ending veinlets. 
lar reticulate. Areolation moderately developed. Freely ending veinlets mostly unbranched, to 2branched. Tooth spacing regular, tooth sinuses angular. Distal tooth flank apically concave and basally convex, tooth proximal flank convex. Leaf surface with simple stipitate glands and peltate scale trichomes, trichomes denser at vein junctions.

Discussion. The subfossil has several features of living Alnus serrulata (Hazel Alder), including strong, non-branching, regularly spaced, approximately alternate secondary veins; very thin, opposite percurrent tertiary veins (Figure 3.1 ); finely serrate leaf margins (Figure 3.1, 3.4); and freely ending veinlets that are usually unbranched (Figure 3.6). The subfossil leaves are similar in overall morphology to other species in the family Betulaceae, especially American Hornbeam (Carpinus caroliniana). However, the presence of both stipitate gland and peltate scale trichomes (Figure 3.2, $3.3,3.5$ ) indicate that it is a member of the genus Alnus (Hardin and Bell, 1986), and its regular, finely serrate teeth distinguish it from other Pennsylvania members of this genus (Rhoads and Block, 2007).

Hazel Alder is native to eastern North America, ranging from Texas to northwest Maine, New Brunswick, and Quebec (United States Department of Agriculture, 2011). It is considered to be an obligate wetland species that grows best at stream margins and in other wet areas including swamps and bogs, although it may also grow on welldrained upland soils (Rhoads and Block, 2007; United States Department of Agriculture, 2011). This species has a rapid growth rate and a high fire tolerance; adult individuals reach a maximum height of approximately nine meters (United States Department of Agriculture, 2011).

\section{Family FAGACEAE Dumortier, 1829 Genus FAGUS Linnaeus, 1753 Fagus grandifolia Ehrhart, 1788 Figure 4}

Material. EMS 425003, EMS 425004 (Figure 4.13, 4.7), EMS 425005 (Figure 4.5).

Description. Lamina elliptic, unlobed, medially symmetrical. Primary venation pinnate. Major secondary veins craspedodromous, attachment to midvein excurrent, spacing regular. Intercostal tertiary veins opposite percurrent, sinuous or occasionally concave, acute to the midvein, angle consistent. Epimedial tertiary veins opposite percurrent, proximal course perpendicular to midvein, distal course parallel to intercostal tertiaries. Quaternary vein fabric mixed percurrent. Areolation moderately developed. Tooth spacing not visible. Distal tooth flank concave; proximal tooth flank flexuous; sinus rounded. Principal vein present. Surface puberulent; trichomes unicellular simple and solitary, with higher densities along major veins and at vein junctions.

Discussion. Observed features that are characteristic of Fagus grandifolia (American Beech) leaves include: regularly spaced secondary veins and opposite-percurrent, low-gauge tertiary veins (Figure 4.1, 4.2); teeth with slightly rounded apices and rounded sinuses that occur approximately once per secondary vein (Figure 4.5); and unicellular, simple, solitary trichomes concentrated along major veins and vein junctions (Figure 4.3, 4.4, 4.7). The subfossils appear similar to other Pennsylvania species of Fagaceae, including Quercus muhlenbergii (Chinkapin Oak) and Castanea dentata (Chestnut), but they are distinguishable from trichome types and tooth morphology. The leaf surface of $C$. dentata generally lacks the simple trichomes seen in F. grandifolia, and it instead may possess fasciculate trichomes not seen in the latter (Hardin and Johnson, 1985). Additionally, leaves of F. grandifolia lack the incurved teeth of Q. muhlenbergii (Rhoads and Block, 2007).

American Beech is native to eastern North America, ranging from Texas, Oklahoma, and Minnesota, east to the Florida panhandle, and north to Quebec, with isolated populations in Utah (United States Department of Agriculture, 2011). Adult individuals typically measure $20-24 \mathrm{~m}$ in height (Coladonato, 1991) and frequently reproduce asexually, forming patches or colonies (Rhoads and Block, 2007). The species is considered to be facultative-upland, but it also grows well in valleybottoms, generally in moist soils (Coladonato, 1991; Rhoads and Block, 2007; United States Department of Agriculture, 2011).

Genus QUERCUS Linnaeus, 1753

Quercus Section Lobatae Loudon, 1830 Figure 5

Material. EMS 425010, EMS 425011 (Figure 5.1-4, 5.6), EMS 425012-425013.

Description. Lobe apices acuminate, angle acute. Inferred major secondary veins craspedodromous; fimbrial vein present, exterior tertiaries looped. Quaternary and higher-order vein fabric random to regular reticulate. Areolation well-developed; freely ending veinlets mostly one-branched. Leaf surface with a few small trichomes on the secondary veins. Stomata randomly oriented, guard cell junctions in T-configuration. 

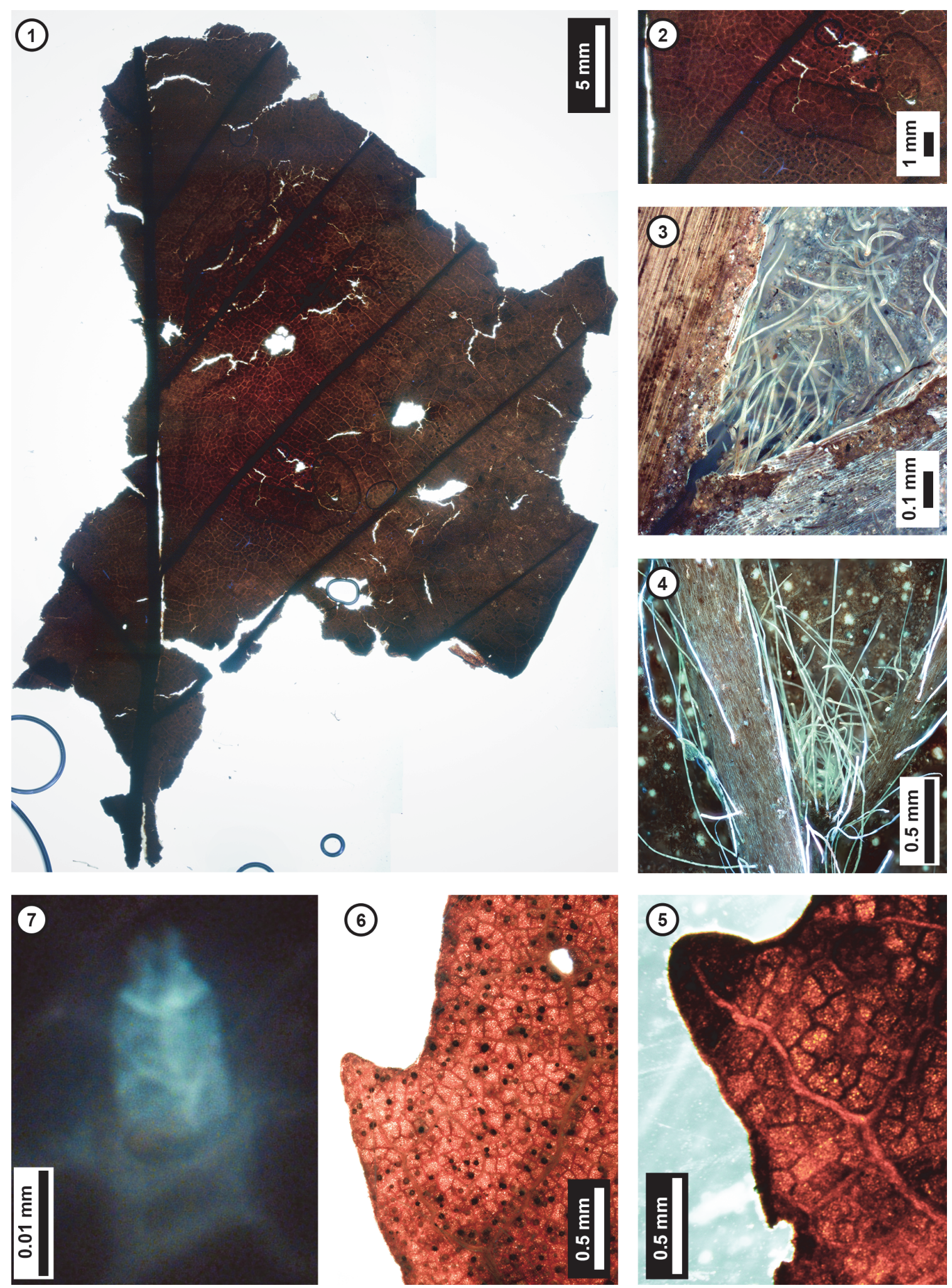

FIGURE 4. Fagus grandifolia (American Beech). 1, Leaf fragment, showing regularly spaced secondary veins, EMS 425004; 2, Detail of venation on EMS 425004; 3, Trichomes at vein junction, EMS 425004; 4, Trichomes at the vein junction of a modern F. grandifolia leaf from York County, Pennsylvania (collection Y1.2 of Wilf, 1997); 5, Rounded tooth on subfossil, EMS 425005; 6 , Tooth and rounded sinus on modern F. grandifolia leaf from York County, Pennsylvania (collection Y1.2 of Wilf, 1997); 7, Trichome, EMS 425004. 

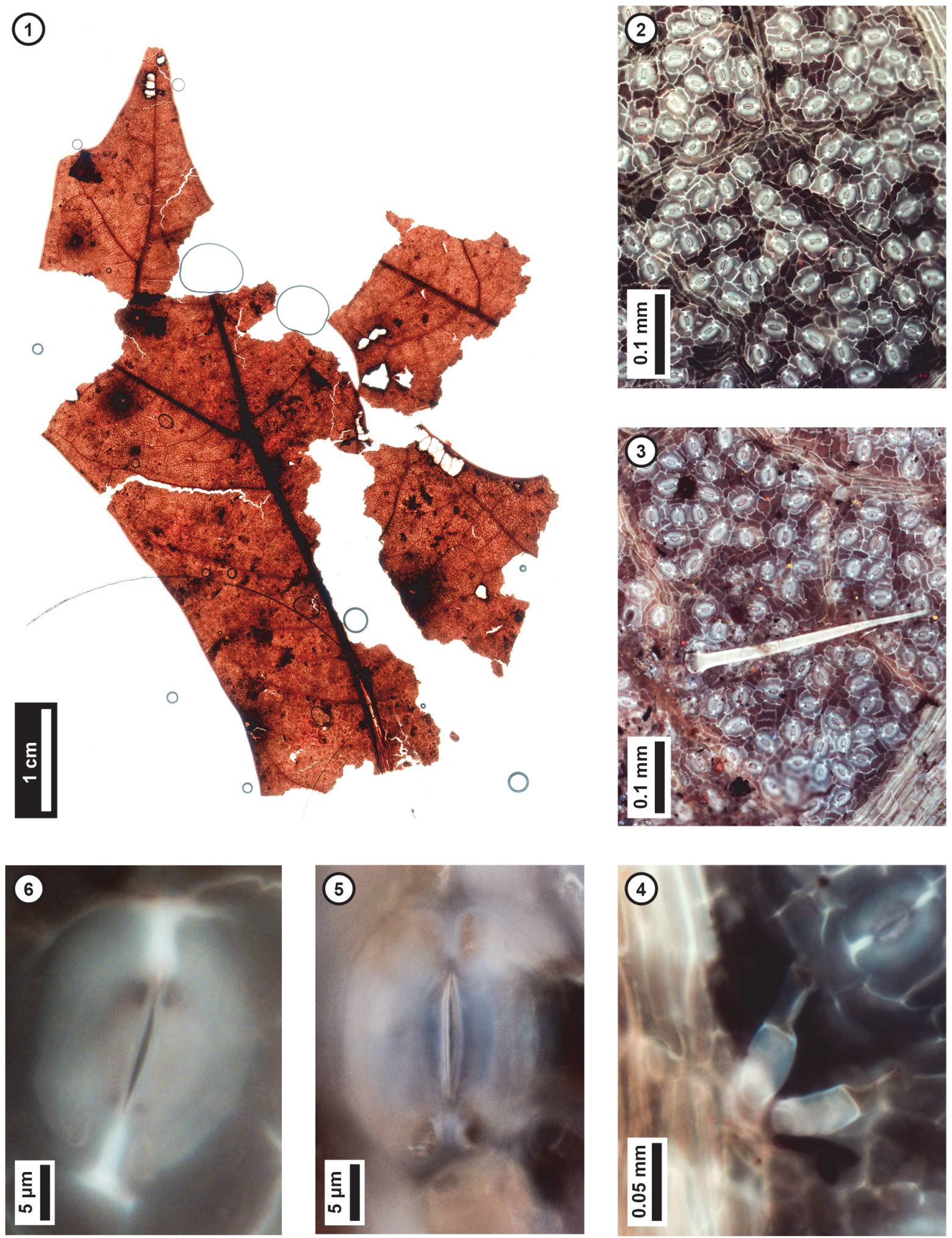

FIGURE 5. Quercus Section Lobatae (Red Oak group). 1, Leaf fragment showing asymmetrical lobe with acute apex, EMS 425011; 2, Abaxial leaf surface of EMS 425011, with randomly oriented stomata; 3, Simple trichome on leaf surface near secondary vein, EMS 425011. 4, Trichomes along a tertiary vein, EMS 425011; 5, Individual stoma of modern Q. rubra from York County, Pennsylvania (collection Y2.3 of Wilf, 1997) showing T-shape junction; 6, Individual stoma of EMS 425011. 
Discussion. These fragments are interpreted as asymmetrical lobe tips with acute apices, fimbrial veins, and marginal irregularities at likely sites of bristle-teeth that were broken off during preservation (Figure 5.1). Only a few, small trichomes persist on the secondary veins (Figure 5.3, 5.4). Stomata are randomly oriented (Figure 5.2, 5.3), and the junction of two guard cells of an individual stoma creates a characteristic T-shape (Figure 5.5, 5.6). These features collectively indicate membership in the red oak group (Quercus Section Lobatae) and, in Pennsylvania, exclude the unlobed species Q. phellos (Rhoads and Block, 2007); however, species-level identification is not possible. The ten species in the red oak group that are native to Pennsylvania vary widely in their environmental preferences (Rhoads and Block, 2007; United States Department of Agriculture, 2011), and without further resolution, these subfossils do not refine environmental interpretation. With the exception of Q. ilicifolia, a shrub, the Pennsylvania species are trees reaching adult heights of 20 -30 meters (Rhoads and Block, 2007).

\section{Quercus Section Quercus Linnaeus, 1753 Figure 6}

Material. EMS 425006-425007, EMS 425008 (Figure 6.2), EMS 425009.

Description. Acute, retuse, lobe apices. Primary venation not preserved. Inferred major secondary vein craspedodromous. Fimbrial vein present. Exterior tertiary veins looped or terminating at margin. Quaternary to $6^{\text {th }}$-order vein fabric irregular reticulate.

Discussion. These fragments are characterized by an entire margin with a fimbrial vein, and a retuse, asymmetrical lobe apex (Figure 6.1). Secondary veins terminate at the lobe apex, and exterior tertiary veins are looped with inconsistent vein angles. Trichomes are uncommon but can be seen scattered across the leaf surface. Species native to Pennsylvania within the white oak group (Quercus Section Quercus) generally have rounded lobe apices, distinguishing them from the bristle-tipped red oak group (Q. Section Lobatae; Rhoads and Block, 2007). The subfossil specimens are inferred from their preserved venation asymmetry to represent rounded lobe apices, indicating both that they belong to the white oak group and that they cannot be Q. muhlenbergii (Chinkapin Oak), which is toothed and unlobed or shallow-lobed (Rhoads and Block, 2007). The apparently glabrous leaf surface suggests that the fragments may represent $Q$. alba (White Oak), however, due to the small amount of tissue preserved, the specimens cannot definitively be identified to species level.

Seven species within the white oak group are native to Pennsylvania and occur within a broad range of environments (Rhoads and Block, 2007; United States Department of Agriculture, 2011). The majority of species, including Quercus alba (White Oak), Q. macrocarpa (Bur Oak), Q. stellata (Post Oak), Q. prinoides (Dwarf Chestnut Oak), Q. muhlenbergii (Chinkapin Oak) and Q. montana (Chestnut Oak), are generally found in non-wetland communities such as hill slopes, ridges, and dry to moist woodlands (Rhoads and Block 2007; United States Department of Agriculture, 2011). However, Swamp White Oak (Quercus bicolor), has a similar leaf morphology to the non-wetland species, but occurs in very different habitats, being frequently found along rivers, on the edges of swamps, and in forested wetlands (Snyder, 1992).

With the exception of $Q$. prinoides, which is usually a shrub, white oak group species are trees growing to approximately 20-30 meters in height (Rhoads and Block, 2007). These species vary in their tolerance to shade, salinity, and fire (United States Department of Agriculture, 2011), as well as their wetland indicator statuses (Rhoads and Block, 2007; United States Department of Agriculture, 2011). Therefore, no environmental interpretations were based on these subfossils.

Family MAGNOLIACEAE Jussieu, 1789

Genus LIRIODENDRON Linnaeus, 1753

Liriodendron tulipifera Linnaeus, 1753

Figure 7

Material. EMS 425015 (Figure 7.1-7.2), EMS 425014 (Figure 7.3).

Description. Samara, elongate, tip mucronate, at the basal seed cavity curving upward and thickened, forming a ridge (Figure 7.2).

Discussion. Liriodendron tulipifera (Tulip Tree) samaras superficially resemble those of various species of ash (Fraxinus spp.). However, ash samaras are flat and unridged, unlike those of $L$. tulipifera and the subfossils, which are curved and ridged (Figure 7.2; McCutchen, 1977; Rhoads and Block, 2007).

Tulip Tree is native to the eastern half of the United States, with isolated populations in Texas. This species has a fast growth rate, and adult individuals typically reach 24-36 meters in height (Rhoads and Block, 2007; United States Department of Agriculture, 2011). Tulip Tree is considered to be a facultative-upland species. It grows well in moist, well drained, neutral to acidic soils and prefers mesic environments (Beck, 1990). It cannot 

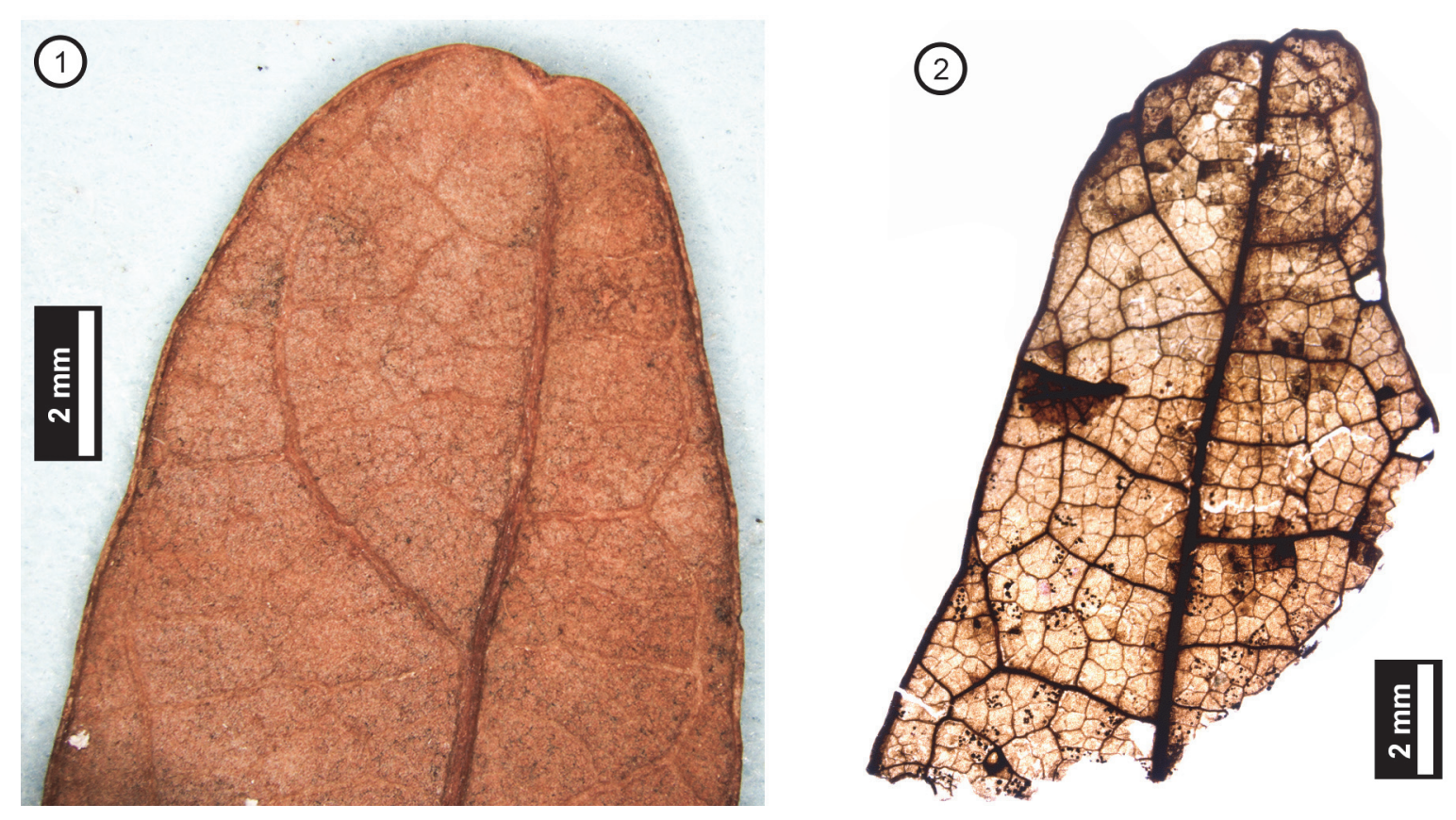

FIGURE 6. Quercus Section Quercus (White Oak group). 1, Lobe of modern Q. alba from York County Pennsylvania (collection of Wilf, 1997); 2, Subfossil, EMS 425008, showing entire margin with fimbrial vein and retuse, asymmetrical apex.

tolerate very wet or dry soils, is shade intolerant, and generally appears early in succession (Beck, 1990; United States Department of Agriculture, 2011).

\section{Family SALICACEAE Mirbel, 1815 \\ Genus SALIX Linnaeus, 1753 \\ Salix spp. \\ Figure 8}

Material. EMS 425022 (Figure 8.1), EMS 425017425020, EMS 425021 (Figure 8.2, 8.4), EMS 425023 (Figure 8.3), EMS 425024-525027.

Description. Lamina unlobed, medially symmetrical. Apex straight, angle acute. Base convex to straight, angle acute. Primary venation pinnate. Major secondary veins semicraspedodromous, spacing and angle inconsistent, attachment to midvein excurrent. Intersecondary veins less-than-one per intercostal area, proximal course acute to midvein, distal course reticulating. Intercostal tertiary veins convex, opposite percurrent to irregular reticulate, obtuse to midvein. Epimedial tertiary veins opposite percurrent to reticulate. Areolation poorly to moderately developed, freely ending veinlets mostly one branched. Tooth spacing regular to irregular, tooth sinuses rounded. Teeth salicoid; principal veins present. Leaf surface without trichomes preserved, possibly glabrous.
Discussion. The subfossils have distinctive salicoid teeth, consisting of one round, dark, nondeciduous seta attached to the tooth apex (Figure 8.4; Hickey and Wolfe, 1975), that place them confidently in Salicaceae. Only two genera of Salicaceae are native to Pennsylvania (Salix, willows, and Populus, cottonwoods and aspens; Rhoads and Block, 2007), and these are readily distinguished because Populus leaves are generally about as wide as they are long, whereas Salix leaves are typically at least two times longer than they are wide (Rhoads and Block, 2007), as seen in the subfossils (Figure 8.1-3). The specimens display both regularly and irregularly spaced teeth. The teeth also vary in orientation and size.

Willows (Salix spp.) are difficult to identify to the species level using leaves alone because a large amount of hybridization occurs between species, and because the typical species-level diagnostic features are not preserved here, such as leaf attachment, catkin morphology, and branching patterns (Argus, 2006). The samples might represent a single or multiple Salix species. Salix species are widely distributed across the world and are generally affiliated with wetland conditions, but they can also grow in drier, upland environments. However, only one willow species native to Pennsylvania, the Prairie Willow (S. humilis), is a facul- 

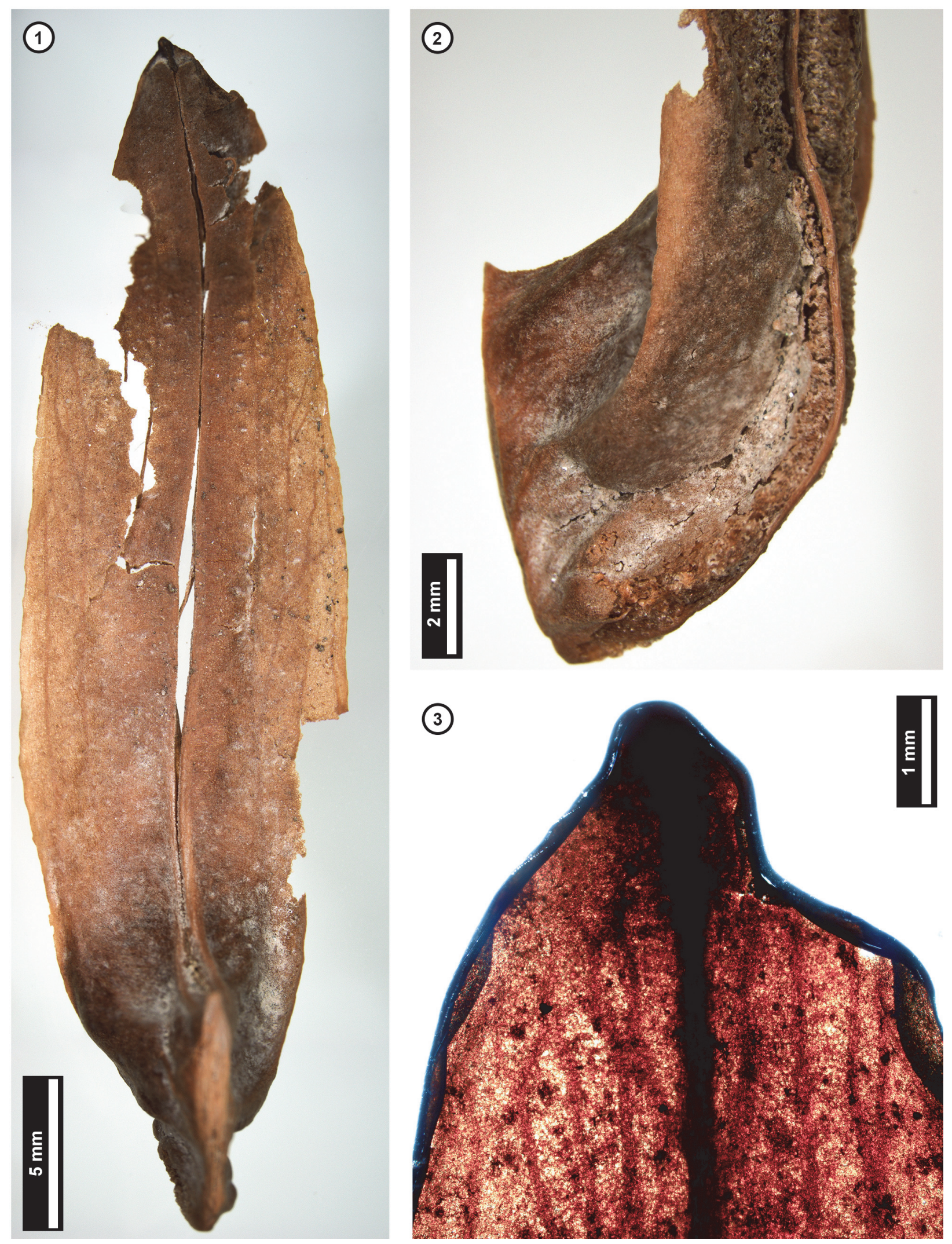

FIGURE 7. Liriodendron tulipifera (Tulip Tree). 1, Subfossil samara, EMS 425015; 2, Thickened ridge at basal attachment site of EMS 425015; 3, Mucronate samara tip from EMS 425014. 

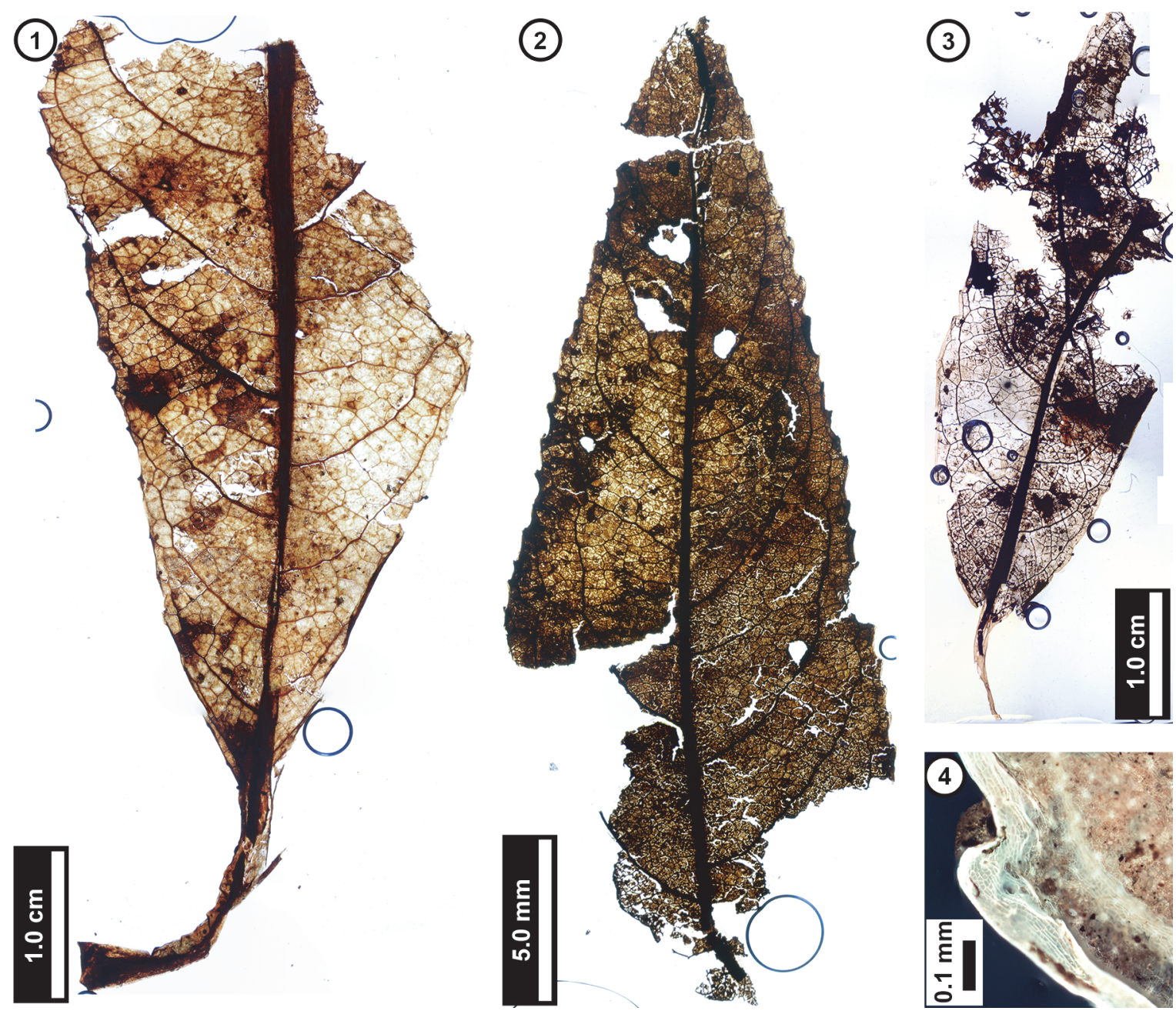

FIGURE 8. Three Salix spp. (Willow) subfossils. 1, EMS 425022; 2, EMS 425021; 3, EMS 425023; 4, Salicoid tooth, EMS 425021.

tative-upland species (United States Department of Agriculture, 2011). That species has variable leaf form, but it frequently has entire margins (Rhoads and Block, 2007) and a tomentose abaxial leaf surface (Argus, 2006; Rhoads and Block, 2007), causing it to appear hairier than many other taxa within the genus. Because the subfossils appear quite different from $S$. humilis in these and other characteristics, we infer that the prehistoric willows were affiliated with a wetland environment.

Family SAPINDACEAE Jussieu, 1789

Genus ACER Linnaeus, 1753

Acer negundo Linnaeus, 1753

Figure 9

Material. EMS 425016 (Figure 9.1-3)

Description. Inferred lateral leaflet, petiolulate, lamina unlobed, ovate, medially asymmetrical with basal width asymmetry. Laminar size nanophyll, length to width ratio 2:1. Base angle obtuse, base shape convex. Apex angle acute, apex shape acuminate. Primary venation pinnate. Major secondary veins semicraspedodromous, irregularly spaced, angle decreasing proximally on one side, attachment to midvein excurrent. Intercostal tertiary veins irregular reticulate. Epimedial tertiary veins reticulate. Higher-order venation indistinct. Tooth spacing irregular with one order of teeth; principal veins present. Tooth sinuses angular to slightly rounded; both distal and proximal flanks basally convex and apically concave. Trichomes simple, restricted to midvein, secondary veins, and leaf margins, increasing in density approaching tooth bases, with no hairs directly above the tooth apex.

Discussion. As seen in the subfossil (Figure 9), Acer negundo (Box Elder) is characterized by asymmetrical, irregularly toothed to shallow-lobed, 

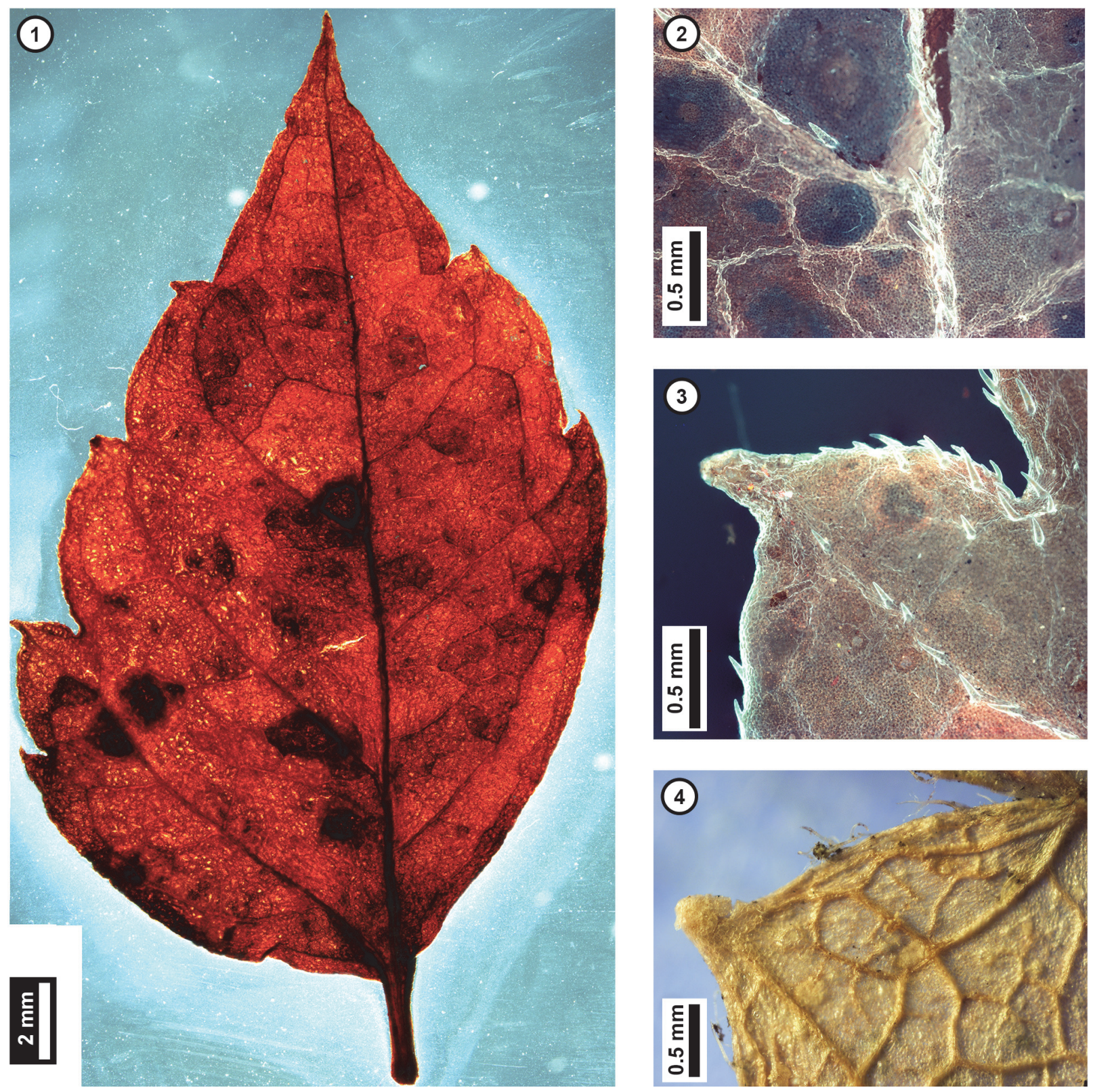

FIGURE 9. Acer negundo (Box Elder). 1, Leaflet, showing shallow lobes and rounded sinuses, EMS 425016; 2, Trichomes along veins, EMS 425016; 3, Trichomes along tooth margin, EMS 425016, with increased density on basal side of tooth; 4, Tooth of modern A. negundo from York County, Pennsylvania (collection Y2.2 of Wilf, 1997), showing the same general trichome pattern.

petiolulate lateral leaflets and simple trichomes that occur only along the midvein, secondary veins, and at leaf margins. Juvenile Acer negundo leaflets may be mistaken for poison ivy (Toxicodendron radicans; United States Department of Agriculture, 2011). Leaflet morphology in both species can be highly variable, making them difficult to distinguish, and both species have marginal trichomes. However, unlike the subfossil, poison ivy leaflets that are toothed usually only have a single or few irreg- ularly-sized teeth, and these have straight or convex, not acuminate, flanks.

Box Elder is a fast-growing, short-lived tree that reaches an average height of approximately 18 meters (United States Department of Agriculture, 2011; Overton, 1990). It has a broad geographic range throughout the eastern two-thirds of the United States and Canada, with isolated populations as far south as Guatemala (Overton 1990). It is considered to be a facultative species with a 
slight affiliation to wetlands (United States Department of Agriculture, 2011). Acer negundo may grow in nearly any soil type but is frequently found in relatively flat areas near streams (Overton, 1990).

\section{DISCUSSION}

This study identifies seven hardwood taxa that inhabited the Piedmont wetlands and valley-margins surrounding White Clay Creek before European settlement in eastern North America. Based on previous work (Walter and Merritts, 2008; Voli et al., 2009; Elliott et al., 2013), we hypothesized that the pre-settlement assemblage would represent the riparian and lower-slope hardwood tree communities and be rich in obligate and facultativewetland species. Although multiple wetland tree species are indeed represented at White Clay Creek, the paleofloral assemblage also contains facultative-wetland, facultative, and facultativeupland species, indicating leaf litter input from multiple topographic sources. Additionally, nearly all the species in the pre-settlement assemblage are not present at the site today, which is dominated by weedy vegetation, indicating that anthropogenic activities significantly altered the floral communities in this region.

\section{Paleocommunity interpretation and comparison}

The White Clay Creek floral assemblage, at face value, does not match any single modern-day forest community. Presumably, the identified taxa represent the preservational mixing of more than one forest type. However, when combined with previously published data from similar nearby sites (Table 3), it becomes possible to fit the data into reconstructions of pre-settlement forest communities.

Walter and Merritts (2008) hypothesized that the modern, single-channel, meandering streams in the northeastern United States seen today were once the locations of broad, tussock-sedge wetlands. The fossil fruit and seed assemblage from Big Spring Run, rich in herbaceous wetland plants (Voli et al., 2009), lends support to this hypothesis. These environments were apparently dominated by herbaceous, wetland-obligate species such as Carex, Polygonum, Eleocharis, Scirpus, Najas, and Brasenia (Voli et al., 2009). However, even though this type of community generally has few shrubs and is entirely devoid of trees (Westervelt et al., 2006), Voli et al. (2009) also reported remains of woody upland taxa including Liriodendron tulipif- era (Tulip Tree) and Juglans cinerea (Butternut), suggesting some input from local slope environments. From the Denlingers Mill site, Elliott et al. (2013) expanded the pre-settlement interpretation by recovering more valley-margin to upslope species, including Fraxinus nigra (Black Ash), Acer rubrum (Red Maple), Platanus occidentalis (American Sycamore), Ostrya virginiana (Eastern Hophornbeam), Betula lenta (Sweet Birch), Acer spicatum (Mountain Maple), and Castanea dentata (American Chestnut).

Despite the physical and historical similarities, there is limited overlap in represented species among the three floras (Table 3). These differences do not necessarily indicate that the sites represent dissimilar forest communities. Instead, they more likely provide snapshots across a similar paleolandscape, from the inundated wetlands to the drier upper hill slopes, due to varying paleotopography and the contrasting taphonomic pathways of the plant organs (Appendix 3). We note that Denlingers Mill is located in a narrow, geologicallyincised part of the valley. An unusual feature of Denlingers Mill not seen at White Clay Creek is a bedrock spur immediately overhanging the leaf layer that presumably was also present in the past, when it supported many of the trees there preserved; this interpretation accounts for the significant representation of upslope species at that site (Elliott et al., 2013).

Based on all available paleobotanical data, the regional valley-margin and lower-slope hardwood communities were probably most similar to either a Red Maple-Tussock Sedge wooded marsh or a Red Maple-Black Ash deciduous swamp forest, which in modern environments both frequently border tussock sedge meadows (Fike, 1999; Westervelt et al., 2006). The most likely analog candidate is the Red Maple-Black Ash swamp forest because it typically has a sedge-dominated understory, and in addition to the two dominant namesake species, this community frequently contains Betula spp., Quercus spp., and Salix spp. as canopy taxa and Alnus serrulata as understory vegetation (Westervelt et al., 2006). Today, this forest community type can be found in the Northern Piedmont, High Allegheny Plateau, and Central Appalachians ecoregions (Westervelt et al., 2006).

The regional pre-settlement upper-slope forest community was probably most similar to either a modern day Northern Piedmont Mesic OakBeech Forest or a Red Oak-American Beech Forest. The Mesic Oak-Beech forest is dominated by Liriodendron tulipifera, Fagus grandifolia, and Bet- 
TABLE 3. Floristic comparison of the White Clay Creek, Big Spring Run, and Denlingers Mill sites.

\begin{tabular}{|c|c|c|c|}
\hline & $\begin{array}{l}\text { White Clay Creek } \\
\text { (this paper) }\end{array}$ & $\begin{array}{l}\text { Big Spring Run } \\
\text { (Voli et al., 2009) }\end{array}$ & $\begin{array}{c}\text { Denlingers Mill } \\
\text { (Elliott et al., 2013) }\end{array}$ \\
\hline Location & $\begin{array}{l}\text { White Clay Creek, } \\
\text { Chester County, PA }\end{array}$ & $\begin{array}{c}\text { Big Spring Run, } \\
\text { Lancaster County, PA }\end{array}$ & $\begin{array}{c}\text { W. Branch Little Conestoga Ck., Lancaster } \\
\text { County, PA }\end{array}$ \\
\hline Material & Leaf and fruit macrofossils & Fruit and seed macrofossils & Leaf and fruit macrofossils \\
\hline Age & 217 to $368 \mathrm{BP}$ & 690 to $3,200 \mathrm{BP}$ & 113 to $295 \mathrm{BP}$ \\
\hline $\begin{array}{l}\text { Herbaceous } \\
\text { species }\end{array}$ & None identified & $\begin{array}{l}\text { Brasenia schreberi, Carex } \\
\text { crinita, C. stipata, C. stricta, } \\
\text { Eleocharis spp., Najas flexilis, } \\
\text { Polygonum spp., Scirpus spp. }\end{array}$ & Present, but none identified \\
\hline $\begin{array}{l}\text { Woody } \\
\text { species }\end{array}$ & $\begin{array}{l}\text { Acer negundo, Alnus serrulata, } \\
\text { Fagus grandifolia, Liriodendron } \\
\text { tulipifera, Quercus Section Lobatae, } \\
\text { Q. Section Quercus, Salix spp. }\end{array}$ & $\begin{array}{l}\text { Juglans cinerea, Liriodendron } \\
\text { tulipifera }\end{array}$ & $\begin{array}{c}\text { Acer rubrum, A. spicatum, Betula lenta, } \\
\text { Castanea dentata, Fagus grandifolia, } \\
\text { Fraxinus nigra, Quercus Section Lobatae, Q. } \\
\text { Section Quercus, Ostrya virginiana, Platanus } \\
\text { occidentalis, Salix spp. }\end{array}$ \\
\hline
\end{tabular}

ula lenta; and, to a lesser extent, Quercus rubra and Q. alba; it is common on gently sloping hills in the Piedmont physiographic province (Westervelt et al., 2006). The Red Oak-American Beech forest, on the other hand, is a broadly defined community that also occurs on mesic sites, but it is rather variable in composition, with dominant canopy species such as Quercus spp., F. grandifolia, and Acer rubrum, and typical subcanopy species including B. lenta, L. tulipifera, and Ostrya virginiana (Fike, 1999; Westervelt et al., 2006).

\section{Comparison to the modern White Clay Creek flora}

Although all seven identified taxa reported here from White Clay Creek are hardwood species native to Pennsylvania, only Liriodendron tulipifera is present in the area today. Instead, weedy species dominate the local riparian vegetation. The area immediately adjacent to the stream, up to three meters from the bank, has no trees or small shrubs. Common taxa in this strip include Jewelweed (Impatiens capensis) and species of Rubus and Solidago (Figure 2). Farther from the stream bank (three to fifteen meters), the vegetation is composed almost entirely of brambly taxa, and although some tree species are present (e.g., L. tulipifera, Fraxinus americana, and exotics such as Ulmus parvifolia and Styphnolobium japonicum), many individuals have been either purposely girdled by humans or are choked with blackberry brambles. This type of vegetation is typical of highly disturbed environments and close proximity to roads and residential areas. All tree species present are either non-native or have facultativeupland affiliations, i.e., L. tulipifera and F. americana. No woody wetland taxa are present, proba- bly due to the well-drained soil and the large (>1 m) distance between the topsoil and the water table.

\section{CONCLUSIONS}

The White Clay Creek flora contributes to our overall understanding of the pre-settlement valleybottom and lower-slope environments by reinforcing results from previously studied paleobotanical sites in southeastern Pennsylvania and through the addition of new species thus far not represented elsewhere, including Acer negundo (Box Elder) and Alnus serrulata (Hazel Alder). Species from at least two different communities, a valley-bottom wetland and an upper slope, are represented in the subfossil assemblage, and nearly all the recovered taxa are absent from the weedy, mostly non-native vegetation present at the study site today. This change is attributed primarily to the results of European settlement in the region, specifically the construction, use, and abandonment of tens of thousands of milldams, as well as to subsequent land use.

The White Clay Creek flora provides a preliminary view of the pre-European settlement forests of Chester County and, in combination with emerging data from other sites, shows which native tree species were once present and could potentially be restored in the area. Restoration efforts that make use of direct paleobotanical evidence for the hardwood species that are best adapted to the landscape should hold the greatest potential for longterm success in the region, including a reduction in legacy sediment loads that cause eutrophication in fragile, downstream estuaries such as Delaware Bay and Chesapeake Bay. 


\section{ACKNOWLEDGMENTS}

We thank I. Grettenberger for assistance with field work and S. Little, M. Carvalho, and R. Coope for help in developing sample cleaning and identification methods. We also thank our colleagues at the Stroud Water Research Center, especially L. Kaplan and A. Aufdenkampe, for their support during our field work activities on White Clay Creek. Funding supporting this work came from the P.D. Krynine Memorial Fund of the Penn State Department of Geosciences and a Geological Society of America Student Research Grant (to CLG), and the David and Lucile Packard Foundation (to $\mathrm{PW}$ ). This research partially completed requirements for a Masters in Geosciences for CLG at Pennsylvania State University, 2011.

\section{REFERENCES}

Aiton, W. 1789. Hortus Kewensis. George Nicol, London, UK.

APG III. 2009. An update of the Angiosperm Phylogeny Group classification for the orders and families of flowering plants. Botanical Journal of the Linnean Society, 161:105-121.

Argus, G.W. 2006. Guide to the identification of the genus Salix (willow) in the Canadian Maritime Provinces (New Brunswick, Nova Scotia, and Prince Edward Island). Alaska Natural Heritage Program, University of Alaska, Anchorage, USA. aknhp.uaa.alaska.edu/botany/salix-salicaceae-identification-using-intkey/.

Asch Sidell, N. 2008. The impact of maize-based agriculture on prehistoric plant communities in the northeast, p. 29-52. In Hart, J.P. (ed.), Current Northeast Paleoethnobotany II. New York State Museum Bulletin Series 512, The University of the State of New York, Albany, New York, USA.

Baker, R.G., Bettis E.A. III, and Horton, D.G. 1993. Late Wisconsinan-early Holocene riparian paleoenvironment in southeastern lowa. Geological Society of America Bulletin, 105:206-212.

Beck, D.E. 1990. Liriodendron tulipifera L., p. 406-416. In Burns, R.M. and Honkala, B. (technical coordinators), Silvics of North America 2. Hardwoods. Agriculture Handbook 654 vol. 2, U.S. Department of Agriculture, Forest Service, Washington, DC, USA.

Behrensmeyer, A.K., Kidwell, S.M., and Gastaldo, R.A. 2000. Taphonomy and paleobiology. Paleobiology, 26:103-147.

Bennion, H., Battarbee, R.W., Sayer, C.D., Simpson, G.L., and Davidson, T.A. 2011. Defining reference conditions and restoration targets for lake ecosystems using palaeolimnology: a synthesis. Journal of Paleolimnology, 45:533-544.

Birks, H.H. and Birks, H.J.B. 2000. Future uses of pollen analysis must include plant macrofossils. Journal of Biogeography, 27:31-35.
Black, B.A., Ruffner, C.M., and Abrams, M.D. 2006. Native American influences on the forest composition of the Allegheny Plateau, northwest Pennsylvania. Canadian Journal of Forest Research, 36:12661275.

Blackmer, Gale C. 2004. Bedrock geologic map of the Pennsylvania portion of the Kennett Square Quadrangle, Chester County, Pennsylvania. Pennsylvania Geological Survey. Report \#OFBM-04-01.0. www.dcnr.state.pa.us/topogeo/publications/pgspub/ openfile/index.htm

Blockhaus, F., Séquaris, J.-M., Narres, H.D., and Schwuger, M.J. 1996. Interactions of a water-soluble polymeric detergent additive (polycarboxylate) with clay minerals from soil. Progress in Colloid and Polymer Science, 101:23-29.

Boesch, D.F., Brinsfield, R.B., and Magnien, R.E. 2001. Chesapeake Bay eutrophication: scientific understanding, ecosystem restoration, and challenges for agriculture. Journal of Environmental Quality, 30:303-320.

Cogbill, C.V. 2000. Vegetation of the pre-settlement forests of northern New England and New York. Rhodora, 102:250-276.

Coladonato, M. 1991. Fagus grandifolia. In: Fire Effects Information System (online). U.S. Department of Agriculture, Forest Service, Rocky Mountain Research Station, Fire Sciences Laboratory. www.fs.fed.us/database/feis/plants/tree/faggra/ all.html

Correll, D.L., Jordan, T.E., and Weller, D.E. 1992. Nutrient flux in a landscape: effects of coastal and use and terrestrial community mosaic on nutrient transport to coastal waters. Estuaries and Coasts, 15:431442.

Costa, J.E. 1975. Effects of agriculture on erosion and sedimentation in the Piedmont Province, Maryland. Geological Society of America Bulletin, 86:12811286.

Davies-Vollum, K.S. and Wing, S.L. 1998. Sedimentological, taphonomic and climatic aspects of Eocene swamp deposits (Willwood Formation, Bighorn Basin, Wyoming). Palaios, 13:28- 40.

Douglas, I. 1994. Sediment transfer and siltation, p. 215234. In Meyer, W.B. and Turner, B.L. II (eds.), Changes in Land Use and Land Cover: a Global Perspective. Cambridge University Press, Cambridge, UK.

Doyle, M.W., Stanley, E.H., Orr, C.H., Selle, A.R., Sethi, S.A., and Harbor, J.M. 2005. Stream ecosystem response to small dam removal: lessons from the heartland. Geomorphology, 71: 227-244.

Dull, R.A. 1999. Palynological evidence for 19th century grazing-induced vegetation change in the southern Sierra Nevada, California, U.S.A. Journal of Biogeography, 26:899-912.

Dumortier, B.C.J. 1829. Analyse des Families des Plantes. J. Casterman, Tournay, France. 
Ehrhart, J.F. 1788. Beiträge zur Naturkunde. Schmidtischen Buchhandlung, Hanover, Germany.

Elliott, S.J., Wilf, P., Walter, R.C., and Merritts, D.J. 2013. Subfossil leaves reveal a new upland hardwood component of the pre-European Piedmont landscape, Lancaster County, Pennsylvania. PLOS ONE 8:e79317. doi: 10.1371/journal.pone.0079317

Ellis, B., Daly, D.C., Hickey, L.J., Johnson, K.R., Mitchell, J.D., Wilf, P., and Wing, S.L. 2009. Manual of Leaf Architecture. Cornell University Press, Ithaca, New York, USA.

FISRWG (Federal Interagency Stream Research Working Group) 2008. Stream corridor restoration: principles, processes, and practices. Natural Resources Conservation Services, Washington D.C., USA. www.nrcs.usda.gov/wps/portal/nrcs/detailfull/ national/water/manage/?\&cid=stelprdb1043244.

Fenneman, N.M. 1938. Physiography of Eastern United States. McGraw-Hill, New York, USA.

Fike, J. 1999. Terrestrial and Palustrine Plant Communities of Pennsylvania. Pennsylvania Department of Conservation and Natural Resources, Harrisburg. www.naturalheritage.state.pa.us/fikebook/terrestrial_plant_book.pdf.

Foster, D.R., Motzkin, G., and Slater, B. 1998. Land-use history as long-term broad-scale disturbance: regional forest dynamics in central New England. Ecosystems, 1:96-119.

Gajewski, K. 1988. Late Holocene climate changes in eastern North America estimated from pollen data. Quaternary Research, 29:255-262.

Gellis, A.C., Hupp, C.R., Pavich, M.J., Landwehr, J.M., Banks, W.S.L., Hubbard, B.E., Langland, M.J., Ritchie, J.C., and Reuter, J.M. 2009. Sources, transport, and storage of sediment at selected sites in the Chesapeake Bay watershed. USGS Scientific Investigations Report \#2008-5186. pubs.usgs.gov/sir/ 2008/5186/.

Goetcheus, V.G. and Birks, H.H. 2001. Full-glacial upland tundra vegetation preserved under tephra in the Beringia National Park, Seward Peninsula, Alaska. Quaternary Science Reviews, 20:135-147.

Gottschalk, L.C. 1945. Effects of soil erosion on navigation in Upper Chesapeake Bay. Geographical Review, 35:219-238.

Gray, S.F. 1821. A Natural Arrangement of British Plants. Baldwin, Cradock and Joy, London, UK.

Greenwood, D.R. 1991. The taphonomy of plant macrofossils, p. 141-169. In Donovan, S.K. (ed.), The Processes of Fossilization. Belhaven Press, London, UK.

Gutshall, M.A. and Oberholtzer, W.L. 2011. Floodplain restoration: basics, benefits, and practical applications. Sustain, 24:14-23.

Hardin, J.W. 1979. Atlas of foliar surface features in woody plants, I. Vestiture and trichome types of eastern North American Quercus. Bulletin of the Torrey Botanical Club, 106:313-325.
Hardin, J.W. and Bell, J.M. 1986. Atlas of foliar surface features in woody plants, IX. Betulaceae of eastern United States. Brittonia, 38:133-144.

Hardin, J.W. and Johnson, G.P. 1985. Atlas of foliar surface features in woody plants, VIII. Fagus and Castanea (Fagaceae) of eastern North America. Bulletin of the Torrey Botanical Club, 112:11-20.

Hartranft, J.L., Merritts, D.J., Walter, R.C., and Rahnis, M. 2011. The Big Spring Run restoration experiment: policy, geomorphology, and aquatic ecosystems in the Big Spring Run watershed, Lancaster County, PA. Sustain, 24:24-30.

Hickey, L.J. and Wolfe, J.A. 1975. The bases of angiosperm phylogeny: vegetative morphology. Annals of the Missouri Botanical Garden, 62:538-589.

Hilgartner, W.B. and Brush, G.S. 2006. Prehistoric habitat stability and post-settlement habitat change in a Chesapeake Bay freshwater tidal wetland, USA. The Holocene, 16:479-494.

Hupp, C.R., Schenk, E.R., Kroes, D.E., Willard, D.A., Townsend, P.A., and Peet, R.K. 2015. Patterns of floodplain sediment deposition along the regulated lower Roanoke River, North Carolina: annual, decadal, centennial scales. Geomorphology, 228:666-680.

James, L.A. 2013. Legacy sediment: definitions and processes of episodically produced anthropogenic sediment. Anthropocene, 2:16-26.

Johnson, P.A. 2014. Defining a standard of care for urban stream restoration projects. Journal of Professional Issues in Engineering Education and Practice, 140:1-5.

Jussieu, A.L. 1789. Genera Plantarum. Barrois, Paris, France.

Kaase, C.T. and Katz, G.L. 2012. Effects of stream restoration on woody riparian vegetation of southern Appalachian mountain streams, North Carolina, U.S.A. Restoration Ecology, 20:647-655.

Kemp, W.M., Boynton, W.R., Adolf, J.E., Boesch, D.F., Boicourt, W.C., Brush, G., Cornwell, J.C., Fisher, T.R., Glibert, P.M., Hagy, J.D., Harding, L.W., Houde, E.D., Kimmel, D.G., Miller, W.D., Newell, R.I.E., Roman, M.R., Smith, E.M., and Stevenson, J.C. 2005. Eutrophication of Chesapeake Bay: historical trends and ecological interactions. Marine Ecology Progress Series, 303:1-29.

Kennen, J. G., Riva-Murray, K., and Beaulieu, K.M. 2010. Determining hydrologic factors that influence stream macroinvertebrate assemblages in the northeastern US. Ecohydrology, 3:88-106.

Kim, S., Toda, Y., and Tsujimoto, T. 2015. Geomorphological and riparian vegetation responses following a low-head dam removal: a study based on literature review. International Journal of River Basin Management, doi: 10.1080/15715124.2015.1012207.

Linnaeus, C. von. 1753. Species Plantarum. L. Salvius, Stockholm, Sweden.

Loudon, J.C. 1830. Loudon's Hortus Britannicus. Longman, Rees, Orme, Brown, and Green, London, UK. 
Macfall, J., Robinette, P., and Welch, D. 2014. Factors influencing bank geomorphology and erosion of the Haw River, a high order river in North Carolina, since European settlement. PLOS ONE 9:e110170. doi:10.1371/journal.pone.0110170.

McCutchen, C.W. 1977. The spinning rotation of ash and tulip tree samaras. Science, 197:691-692.

Merritts, D., Walter, R., and Rahnis, M.A. 2010a. Sediment and nutrient loads from stream corridor erosion along breached millponds. Franklin and Marshall College Report, Lancaster, Pennsylvania. https:// edisk.fandm.edu/michael.rahnis/outgoing/DEP/ DEP_REPORT_TEXT.pdf

Merritts, D., Walter, R., and Rahnis, M.A. 2010bWaterpowered milling and its legacy as a source of suspended sediment to the Susquehanna River and Chesapeake Bay. Susquehanna River Basin Commission, Harrisburg, PA. www.srbc.net/stateofsusq2010/documents/ legacysedimentsfeaturearticle.pdf

Merritts, D., Walter, R., Rahnis, M., Cox, S., Hartranft, J., Scheid, C., Potter, N., Jenschke, M., Reed, A., Matuszewski, D., Kratz, L., Manion, L., Shilling, A., and Datin, K. 2013. The rise and fall of Mid-Atlantic streams: Millpond sedimentation, milldam breaching, channel incision, and stream bank erosion. Geological Society of America Reviews in Engineering Geology, 21:183-203.

Middleton, A.P. 1953. Tobacco Coast: a maritime history of Chesapeake Bay in the colonial era. The Mariners' Museum, Newport News, Virginia, USA.

Miller, C.L. 2011. Lessons from Soggy Leaves: a PreSettlement Flora from White Clay Creek, Chester County, Pennsylvania. Masters Thesis. The Pennsylvania State University, University Park.

Miller, P. 1754. The Gardeners Dictionary, Abridged. Fourth Edition. John and James Rivington, London, UK.

Mirbel, C.F.B. 1815. Éléments de Physiologie Végétale et de Botanique. Magimel, Paris, France.

Niemitz, J., Haynes, C., and Lasher, G. 2013. Legacy sediments and historic land use: chemostratigraphic evidence for excess nutrient and heavy metal sources and remobilization. Geology, 41:47-50.

Newbold, J.D., Bott, T.L., Kaplan, L.A., Sweeney, B.W., and Vannote, R.L. 1997. Organic matter dynamics in White Clay Creek, Pennsylvania, USA. Journal of the North American Benthological Society, 16:46-50.

Orth, R.J. and Moore, K.A. 1983. Chesapeake Bay: an unprecedented decline in submerged aquatic vegetation. Science, 222:51-53.

Overton, R.P. 1990. Acer negundo L., p. 41-45. In Burns, R.M. and Honkala, B. (technical coordinators), Silvics of North America 2. Hardwoods. Agriculture Handbook 654 vol. 2, U.S. Department of Agriculture, Forest Service, Washington, DC.

Palmer, M.A., Bernhardt, E.S., Allan, J.D., Lake, P.S., Alexander, G., Brooks, S., Carr, J., Clayton, S., Dahm, C.N., Follstad Shah, J., Galat, D.L., Loss,
S.G., Goodwin, P., Hart, D.D., Hassett, B., Jenkinson, R., Kondolf, G.M., Lave, R. Meyer, J.L., O'Donnell, T.K., Pagano, L., and Sudduth, E. 2005. Standards for ecologically successful river restoration. Journal of Applied Ecology, 42:208-217.

Pennock, J.R. Sharp, J.H., and Schroeder, W.W. 1994. What controls the expression of estuarine eutrophication? Case studies of nutrient enrichment in the Delaware Bay and Mobile Bay estuaries, USA, p. 139-146. In Dyer, K.R. and Orth, R.J. (eds.), Changes in Fluxes in Estuaries: Implications from Science to Management. Olsen and Olsen, Fredensborg, Denmark.

Pizzuto, J. and O'Neal, M. 2009. Increased mid-twentieth century riverbank erosion rates related to the demise of mill dams, South River, Virginia. Geology, 37:1922.

Reimer, P.J., Bard, E., Bayliss, A., Beck, J.W., Blackwell, P.G., Bronk-Ramsey, C., Buck, C.E., Cheng, H., Edwards, R.L., Friedrich, M., Grootes, P.M., Guilderson, T.P., Haflidason, H., Hajdas, I., Hatte, C., Heaton, T.J., Hogg, A.G., Hughen, K.A., Kaiser, K.F., Kromer, B., Manning, S.W., Niu, M., Reimer, R.W., Richards, D.A., Scott, E.M., Southon, J.R., Turney, C.S.M., and van der Plicht, J. 2013. IntCal13 and MARINE13 radiocarbon age calibration curves 050000 years calBP. Radiocarbon, 55:1869-1887.

Rhoads, A.F. and Block, T.A. 2007. The Plants of Pennsylvania, an Illustrated Manual, $2^{\text {nd }}$ ed. University of Pennsylvania Press, Philadelphia, Pennsylvania, USA.

Richardson, D.M., Holmes, P.M., Esler, K.J., Galatowitsch, S.M., Stromberg, J.C., Kirkman, S.P., Pyšek, P., and Hobbs, R.J. 2007. Riparian vegetation: degradation, alien plant invasions, and restoration prospects. Diversity and Distributions, 13:126-139.

Shafroth, P.B., Stromberg, J.C., and Patten, D.T. 2002. Riparian vegetation response to altered disturbance and stress regimes. Ecological Applications, 12:107123.

Sharpley, A., Jarvie, H.P., Buda, A., May, L., Spears, B., and Kleinman, P. 2013. Phosphorus legacy: overcoming the effects of past management practices to mitigate future water quality impairment. Journal of Environment Quality, 42:1308-1326.

Simon, A. 1989. The discharge of sediment in channelized alluvial streams. Journal of the American Water Resources Association, 6:1177-1188.

Smucker, N. J. and Detenbeck, N. E. 2014. Meta-analysis of lost ecosystem attributes in urban streams and the effectiveness of out-of-channel management practices. Restoration Ecology, 22:741-748.

Snyder, S.A. 1992. Quercus bicolor L. In: Fire Effects Information System (online). U.S. Department of Agriculture, Forest Service, Rocky Mountain Research Station, Fire Sciences Laboratory. www.fs.fed.us/database/feis/plants/tree/quebic/ all.html 
Springer, G.S., White, D.M., Rowe, H.D., Hardt, B., Nivanthi Mihimdukulasooriya, L., Cheng, H., and Edwards, R.L. 2010. Multiproxy evidence from caves of Native Americans altering the overlying landscape during the late Holocene of east-central North America. The Holocene, 20:275-283.

Stanley, E.H. and Doyle, M.W. 2002. A geomorphic perspective on nutrient retention following dam removal. Bioscience, 52:693-701.

Stanley, E.H. and Doyle, M.W. 2003. Trading off: the ecological effects of dam removal. Frontiers in Ecology and the Environment, 1:15-22.

Stearn, W.T. 2004. Botanical Latin. Timber Press, Portland, Oregon, USA.

Stephens, J.L. 2014. Short term response of vegetation and birds to dam removal on the Rogue River, Oregon. Report No. KBO-2014-0011. Klamath Bird Observatory, Ashland, Oregon, USA. www.rvcog.org/ KBO\%20Bird.pdf

Stinchcomb, G.E., Messner, T.C., Driese, S.G., Nordt, L.C., and Stewart, R.M. 2011. Pre-colonial (A.D. 1100-1600) sedimentation related to prehistoric maize agriculture and climate change in eastern North America. Geology, 39:363-366.

Thompson, J. R., Carpenter, D.N., Cogbill, C.V., and Foster, D.R. 2013. Four centuries of change in northeastern United States forests. PLoS ONE, 8:e72540. doi: 10.1371/journal.pone.0072540

Traverse, A. 2008. Paleopalynology, $2^{\text {nd }}$ ed. Springer, Dordrecht, Netherlands. United States Department of Agriculture, Natural Resources Conservation Service, 2011. The PLANTS Database. National Plant Data Center, Baton Rouge, Louisiana. plants.usda.gov

Voli, M., Merritts, D., Walter, R., Ohlson, E., Datin, K., Rahnis, M., Kratz, L., Deng, W., Hilgartner, W., and Hartranft, J. 2009. Preliminary reconstruction of a pre-European settlement valley-bottom wetland, southeastern Pennsylvania. Water Resources Impact, 11:11-13.

Voli, M. T., Wegmann, K.W., Bohnenstiehl, D.R., Leithold, E., Osburn, C.L., and Polyakov, V. 2013. Fingerprinting the sources of suspended sediment delivery to a large municipal drinking water reservoir: Falls Lake, Neuse River, North Carolina, USA. Journal of Soils and Sediments, 13:1692-1707.

Walter, R.C. and Merritts, D.J. 2008. Natural streams and the legacy of water-powered mills. Science, 319:299-304.
Walter, R.C., Merritts, D.J., and Rahnis, M. 2007. Estimating volume, nutrient content and rates of stream bank erosion of legacy sediment in the Piedmont and Valley and Ridge Physiographic Provinces, Southeastern and Central PA: A report to the Pennsylvania Department of Environmental Protection. files.dep.state.pa.us/Water/Chesa-

peake\%20Bay\%20Program/lib/chesapeake/pdfs/ padeplegacysedimentreport2007waltermerrittsrahnisfinal.pdf

Wegmann, K.W., Lewis, R.Q., and Hunt, M.C. 2012. Historic mill ponds and Piedmont stream water quality: making the connection near Raleigh, North Carolina, p. 93-121. In Eppes, M.C. and Bartholomew, M.J. (eds.), From the Blue Ridge to the Coastal Plain: Field Excursions in the Southeastern United States. Geological Society of America Field Guide 29.

Wegmann, K.W, Osburn, C.L., Lewis, R.Q., Peszlen, I.M., and Mitasova, H. 2013. Legacy sediments and stream water quality: estimating volume, nutrient content, and stream bank erosion in 303(d)-impaired waterways of the North Carolina Piedmont. Report number NC-WRRI-435. Water Resources Research Institute of the University of North Carolina, Raleigh, North Carolina, USA.

Weisberg, P.J., Mortenson, S.G., and Dilts, T.E. 2013. Gallery forest or herbaceous wetland? The need for multi-target perspectives in riparian restoration planning. Restoration Ecology, 21:12-16.

Weitzman, J.N., Forshay, K.J., Kaye, J.P., Mayer, P.M., Koval, J.C., and Walter, R.C. 2014. Potential nitrogen and carbon processing in a landscape rich in milldam legacy sediments. Biogeochemistry, 120:337-357.

Weslager, C.A. 1955. Log houses in Pennsylvania during the seventeenth century. Pennsylvania History, 22:256-266.

Westervelt, K., Largay, E., Coxe, R., McAvoy, W., Perles, S., Podniesinski, G., Sneddon, L., and Strakosch Walz, K. 2006. A guide to the natural communities of the Delaware Estuary: Version 1, PDE Report No. 06-02. NatureServe, Arlington, Virginia, USA.

Willdenow, C.L. von. 1805. Species Plantarum, 4:336.

Wilf, P. 1997. When are leaves good thermometers? A new case for Leaf Margin Analysis. Paleobiology, 23:373-390.

Wing, S.L. and DiMichele, W.A. 1995. Conflict between local and global changes in plant diversity through geologic time. Palaios, 10:551-564. 


\section{APPENDIX 1.}

\section{Historical background}

Prior to European settlement, the North American landscape was already altered by Native American activities. Charcoal, isotope, and archeological evidence suggest that tribes along the East Coast used fire to clear forests long before European settlers arrived (Douglas, 1994; Springer et al., 2010). These activities created small but noticeable changes in the pollen record, including decreased contributions from forest taxa and increased representation from crop, disturbance, and early successional species (Baker et al., 1993; Black et al., 2006). Additionally, deposits in New Jersey and Pennsylvania indicate that Native American maize agriculture caused decreased forest cover and increased sedimentation in valley-bottoms between 1000 and $1600 \mathrm{C}$.E. (Stinchcomb et al., 2011). Therefore, floodplains were both hydrologically and ecologically altered by prehistoric peoples (Asch Sidell, 2008; Stinchcomb et al., 2011); however, the magnitude and impact of these alterations were significantly less than those caused by European settlers during the seventeenth and eighteenth centuries.

European settlement significantly affected the hydrogeomorphology and associated wetland and riparian flora throughout the Piedmont region due, in large part, to the mills, forges, furnaces, and mining operations settlers built to support their communities (Walter and Merritts, 2008; Voli et al., 2009; Wegmann et al., 2012). These structures were dependent on hydropower provided by tens of thousands of dams erected on streams throughout the region (Walter and Merritts, 2008; Merritts et al., 2013). In addition to this expansive infrastructure, European colonists transformed hundreds of thousands of acres of upland, old-growth forest into agricultural fields in the northeastern United States (Costa, 1975; Thompson et al., 2013). Many of the crops planted, such as tobacco, were harmful to soil quality, so settlers frequently cleared more land as fields were exhausted and abandoned after a few seasons (Gottschalk, 1945; Middleton, 1953).

These agricultural clearing and tilling practices triggered large-scale topsoil erosion throughout the Piedmont region (Costa, 1975; James, 2013; Merritts et al., 2013). The fine-grained, extremely mobile, phosphorus and nitrogen-rich silts deposited in valley-bottoms and floodplains from colonial activities are collectively referred to as "legacy sediments" (Walter and Merritts, 2008; James, 2013).

Dams built across the valley-bottoms decreased flow velocity by up to $60 \%$, causing the legacy sediments to settle out of the water column and to form alluvial deposits behind milldams that could stretch hundreds of meters, often upstream to the next dam (Walter and Merritts, 2008; Merritts et al., 2010b; Merritts et al., 2013). In the Pennsylvania Piedmont, two-thirds of this sediment was eventually deposited on modified floodplains and on lower hill slopes within river valleys, causing several meters of floodplain elevation relative to hydrologic base level along the entire lengths of streams and across the entire widths of valley floors (Walter and Merritts, 2008; Hartranft et al., 2011; James, 2013; Wegmann et al., 2013; Weitzman et al., 2014).

As alternative energy sources became available, dams were either removed or abandoned and eventually breached (Merritts et al., 2013). These events triggered stream incision through the reservoir sediments, ultimately forming meandering streams with elevated banks and characteristic water flow patterns involving fast-flowing riffles with artificially steep gradients at dam sites, and pools where ponds had formed behind the milldams (Simon, 1989; Walter and Merritts, 2008; Merritts et al., $2010 \mathrm{~b})$. This process was repeated tens of thousands of times across the landscape, dramatically shifting the hydrogeomorphology of first to third order streams from small, vegetated, anabranching channels that were well-connected with the water table and their floodplains to the single-channel, steep-banked streams seen today (Simon, 1989; Walter and Merritts, 2008; Voli et al., 2009; Hartranft et al., 2011). 


\section{APPENDIX 2.}

\section{Environmental restoration}

Increasingly accurate models of the regional pre-settlement wetland and riparian zone flora, especially including trees, are critical for guiding restoration and conservation decisions to ensure a resulting, functioning ecosystem (Weisberg et al., 2013; Johnson, 2014; Smucker and Detenbeck, 2014). Communities assembled from Holocene floral reconstructions can be carefully used as baseline targets for restoration and conservation projects in areas influenced by human activities (Palmer et al., 2005; Bennion et al., 2011).

Post-milldam streams with pools, riffles, and point bars (Walter and Merritts, 2008) were once considered "natural", and they were commonly used as models for environmental restoration projects. However, the experimental "restorations" continued to modify riparian zone vegetation and prevent streams from breaching onto their floodplains (FISRWG, 2008), resulting in limited overall success (Gutshall and Oberholtzer, 2011; Hartranft et al., 2011). Recently, it has been demonstrated that a more sustainable approach is to completely remove legacy sediments, then restore the naturally occurring riparian vegetation at the original base level wherever possible (Voli et al., 2009; Gutshall and Oberholtzer 2011; Hartranft et al., 2011; Niemitz et al., 2013). Rapid planting of native flora, including hardwood trees, following legacy sediment removal is necessary because weedy species are more likely to colonize the disturbed environment first, excluding the native riparian vegetation and decreasing ecosystem function and riparian zone restoration success (Shafroth et al., 2002; Stanley and Doyle, 2003; Doyle et al., 2005; Gutshall and Oberholtzer, 2011; Kaase and Katz, 2012). More than three decades may be needed for hardwood species to recolonize an altered area after dam removal (Stephens, 2014; Kim et al., 2015), and vegetation along the riparian zone is one of the most important drivers of restoration success (FISRWG, 2008; Gutshall and Oberholtzer, 2011).

Successful restoration, including reestablishing a stream's access to its floodplain, reducing erosion, and creating a self-sustaining wetland and riparian zone, necessitates an understanding of the pre-European settlement floral community. After removal of legacy sediments, future restoration efforts that plant documented prehistoric wetland and lowland species, including those described in this study, may be able to recreate native and ecologically functional riparian and valley-margin forests that closely mimic the unaltered environment. Additionally, restoration projects that include legacy sediment removal and the re-establishment of native species in the riparian zone can decrease the amount of sediment eroded and transported to downstream areas like the Chesapeake Bay (Correll et al., 1992; Walter et al., 2007; Gutshall and Oberholtzer, 2011). 


\section{APPENDIX 3.}

\section{Advantages of subfossil leaves}

Most Holocene floral reconstructions are based on fossil pollen because it is often abundant and well preserved (Gajewski, 1988; Dull, 1999). However, pollen is susceptible to temporal and spatial averaging, and it is frequently only identifiable to the genus level (Birks and Birks, 2000). Fruits, seeds, and woods are also regularly used, but they are likewise prone to temporal and spatial averaging and are frequently not identifiable to the species level. On the other hand, Holocene leaves are usually identifiable to the species level and represent the most temporally and spatially localized information because they cannot be reworked. However, leaf subfossils are not often used because they are fragile, difficult to process, and quite rare in comparison to more durable fruits, seeds, woods, and palynomorphs (Goetcheus and Birks, 2001). Fruit, seed, and pollen assemblages are generally considered to have temporal resolutions of $10^{2}-10^{4}$ years because they are highly resistant to decomposition and abrasion and are therefore prone to reworking, redeposition, and temporal averaging (Behrensmeyer et al., 2000; Greenwood, 1991). In contrast, leaf floras are considered to have higher temporal resolution, generally between $10^{-1}$ and $10^{1}$ years (Behrensmeyer et al., 2000; Birks and Birks, 2000). Additionally, leaf macrofossils frequently represent a more local community than either fossil pollen or seeds because they are transported shorter distances (Wing and DiMichele, 1995; Davies-Vollum and Wing, 1998; Behrensmeyer et al., 2000; Birks and Birks, 2000). When combined with published paleontological data from seeds and pollen, community reconstructions based on leaf macrofossils can overcome many of the spatial and temporal disadvantages associated with pollen and seeds alone, providing a more accurate view of ancient communities (Birks and Birks, 2000). 


\section{APPENDIX 4.}

White Clay Creek specimen data

\begin{tabular}{|c|c|c|c|c|}
\hline ID & Organ & Field Number & EMS Number & Figure Number \\
\hline Alnus serrulata & Leaf & LMS 3 & 425002 & 3 \\
\hline Fagus grandifolia & Leaf & LMS 13.3 & 425003 & \\
\hline Fagus grandifolia & Leaf & LMS 14.9 & 425004 & $4.1-4.3,4.7$ \\
\hline Fagus grandifolia & Leaf & LMS 30.2 & 425005 & 4.5 \\
\hline Quercus Section Lobatae & Leaf & LMS 33.2 & 425010 & \\
\hline Quercus Section Lobatae & Leaf & LMS 57 & 425011 & $5.1-5.4,5.6$ \\
\hline Quercus Section Lobatae & Leaf & LMS 60 & 425012 & \\
\hline Quercus Section Lobatae & Leaf & LMS 61 & 425013 & \\
\hline Quercus Section Quercus & Leaf & LMS 21.3 & 425006 & \\
\hline Quercus Section Quercus & Leaf & LMS 22.2 & 425007 & \\
\hline Quercus Section Quercus & Leaf & LMS 22.3 & 425008 & 6.2 \\
\hline Quercus Section Quercus & Leaf & LMS 22.9 & 425009 & \\
\hline Liriodendron tulipifera & Fruit & LMS 44.1 & 425014 & 7.3 \\
\hline Liriodendron tulipifera & Fruit & LMS 54 & 425015 & $7.1-7.2$ \\
\hline Salix sp. & Leaf & LMS 6 & 425017 & \\
\hline Salix sp. & Leaf & LMS 8.1 & 425018 & \\
\hline Salix sp. & Leaf & LMS 16.1 & 425019 & \\
\hline Salix sp. & Leaf & LMS 22.7 & 425020 & \\
\hline Salix sp. & Leaf & LMS 31.1 & 425021 & $8.2,8.4$ \\
\hline Salix sp. & Leaf & LMS 32.1 & 425022 & 8.1 \\
\hline Salix sp. & Leaf & LMS 35.3 & 425023 & 8.3 \\
\hline Salix sp. & Leaf & LMS 52 & 425024 & \\
\hline Salix sp. & Leaf & LMS 53 & 425025 & \\
\hline Salix sp. & Leaf & LMS 55 & 425026 & \\
\hline Salix sp. & Leaf & LMS 59 & 425027 & \\
\hline Acer negundo & Leaf & LMS 50 & 425016 & $9.1-9.3$ \\
\hline Unknown & Leaf & LMS 0.01 & 425028 & \\
\hline Unknown & Leaf & LMS 0.02 & 425029 & \\
\hline Unknown & Leaf & LMS 0.09 & 425030 & \\
\hline Unknown & Leaf & LMS 1.12 & 425031 & \\
\hline Unknown & Leaf & LMS 14.01 & 425032 & \\
\hline Unknown & Leaf & LMS 14.04 & 425033 & \\
\hline Unknown & Leaf & LMS 14.09.2 & 425034 & \\
\hline Unknown & Leaf & LMS 14.09.3 & 425035 & \\
\hline Unknown & Leaf & LMS 14.09.4 & 425036 & \\
\hline Unknown & Leaf & LMS 14.11 & 425037 & \\
\hline Unknown & Leaf & LMS 15.06 & 425038 & \\
\hline
\end{tabular}


Elliott et al.: Pre-colonial Piedmont forests

Appendix 4 (continued).

\begin{tabular}{|c|c|c|c|c|}
\hline ID & Organ & Field Number & EMS Number & Figure Number \\
\hline Unknown & Leaf & LMS 16.05 & 425039 & \\
\hline Unknown & Leaf & LMS 16.07 & 425040 & \\
\hline Unknown & Leaf & LMS 16.09 & 425041 & \\
\hline Unknown & Leaf & LMS 16.12 & 425042 & \\
\hline Unknown & Leaf & LMS 21.04 & 425043 & \\
\hline Unknown & Leaf & LMS 21.05 & 425044 & \\
\hline Unknown & Leaf & LMS 22.05 & 425045 & \\
\hline Unknown & Leaf & LMS 23 & 425046 & \\
\hline Unknown & Leaf & LMS 23.2 & 425047 & \\
\hline Unknown & Leaf & LMS 28.06 & 425048 & \\
\hline Unknown & Leaf & LMS 3.02 & 425049 & \\
\hline Unknown & Leaf & LMS 30.01 & 425050 & \\
\hline Unknown & Leaf & LMS 30.04 & 425051 & \\
\hline Unknown & Leaf & LMS 33.1 & 425052 & \\
\hline Unknown & Leaf & LMS 40.1 & 425053 & \\
\hline Unknown & Leaf & LMS 42.03 & 425054 & \\
\hline Unknown & Leaf & LMS 43.1 & 425055 & \\
\hline Unknown & Leaf & LMS 47 & 425056 & \\
\hline Unknown & Leaf & LMS 48 & 425057 & \\
\hline Unknown & Leaf & LMS 49 & 425058 & \\
\hline Unknown & Leaf & LMS 56 & 425059 & \\
\hline Unknown & Leaf & LMS 58 & 425060 & \\
\hline Unknown & Leaf & LMS 8.02 & 425061 & \\
\hline Unknown & Leaf & LMS 8.03 & 425062 & \\
\hline Unknown & Leaf & LMS DW 1.03 & 425063 & \\
\hline
\end{tabular}

